FEDERAL RESERVE BANK OF SAN FRANCISCO

WORKING PAPER SERIES

\title{
Navigating the Trilemma: Capital Flows and Monetary Policy in China
}

\author{
Reuven Glick \\ Federal Reserve Bank of San Francisco \\ Michael Hutchison \\ University of California, Santa Cruz
}

December 2008

Working Paper 2008-32

http://www.frbsf.org/publications/economics/papers/2008/wp08-32bk.pdf

\begin{abstract}
The views in this paper are solely the responsibility of the authors and should not be interpreted as reflecting the views of the Federal Reserve Bank of San Francisco or the Board of Governors of the Federal Reserve System. This paper was produced under the auspices of the Center for Pacific Basin Studies within the Economic Research Department of the Federal Reserve Bank of San Francisco.
\end{abstract}




\title{
Navigating the Trilemma: Capital Flows and Monetary Policy in China
}

\author{
December 2008
}

\author{
Reuven Glick \\ Economic Research Department \\ Federal Reserve Bank of San Francisco \\ reuven.glick@sf.frb.org
}

\author{
Michael Hutchison \\ Department of Economics \\ University of California, Santa Cruz \\ hutch@ucsc.edu
}

\begin{abstract}
:
In recent years China has faced an increasing trilemma-how to pursue an independent domestic monetary policy and limit exchange rate flexibility, while at the same time facing large and growing international capital flows. This paper analyzes the impact of the trilemma on China's monetary policy as the country liberalizes its goods and financial markets and integrates with the world economy. It shows how China has sought to insulate its reserve money from the effects of balance of payments inflows by sterilizing through the issuance of central bank liabilities. However, we report empirical results indicating that sterilization dropped precipitously in 2006 in the face of the ongoing massive buildup of international reserves, leading to a surge in reserve money growth. We estimate a vector error correction model linking the surge in China's reserve money to broad money, real GDP, and the price level. We use this model to explore the inflationary implications of different policy scenarios. Under a scenario of continued rapid reserve money growth (consistent with limited sterilization of foreign exchange reserve accumulation) and strong economic growth, the model predicts a rapid increase in inflation. A model simulation using an extension of the framework that incorporates recent increases in bank reserve requirements also implies a rapid rise in inflation. By contrast, model simulations incorporating a sharp slowdown in economic growth lead to less inflation pressure even with a substantial buildup in international reserves.
\end{abstract}

The views expressed below do not represent those of the Federal Reserve Bank of San Francisco or the Board of Governors of the Federal Reserve System. Hutchison's work on this project was started while a visiting fellow at the Hong Kong Institute for Monetary Research (HKIMR). We thank Kenneth Chow and Katherine Chen for excellent research assistance and Dong He for data. We also thank participants at the conference "Global Liquidity and East Asian Economies" held at the HKMIR in Hong Kong on June 26-27, 2008, especially our discussants Hiro Ito, Hans Genberg, and Dong He, as well as participants at the American Committee on Asian Economic Studies (ACAES) conference “Asian Economic Integration in a Global Context” held in Rimini, Italy, for helpful comments. 


\section{Introduction}

The trilemma paradigm of open economy macroeconomics asserts that a country may not simultaneously target the exchange rate, run an independent monetary policy, and allow full capital mobility. ${ }^{1}$ In the mid to late 1980 s most developing countries addressed the trilemma by maintaining a combination of exchange rate stability and monetary independence, with relatively closed capital accounts. In the late 1980s and early 1990s, some developing countries, such as Mexico, Thailand, and Korea, embraced growing financial liberalization and openness. However, as they opened more financially, many of these countries also tried to maintain some degree of exchange rate stability and monetary independence, and failed to successfully navigate the trilemma. Their inconsistent policy goals resulted in severe financial crises, in Mexico during 1994-95 and in Asia during 1997-98. In the early 1990s Argentina adopted another trilemma configuration involving exchange rate fixity, supported by a version of a currency board, and complete financial integration. Argentina also experienced a crisis when ceding monetary policy independence to a currency board arrangement was no longer viable.

China has pursued a more cautious path towards greater financial openness. Although tax benefits and other incentives have been used to promote inward foreign direct investment, other forms of inflows, particularly portfolio capital and external debt, have been traditionally discouraged. Capital controls have also played a role in protecting the banking system from external competition by restricting the entry of foreign banks and by making it harder for capital to flow out of the country. The limited development of debt and equity markets in the past preserved the role of the state-owned banking system as the main international intermediary for Chinese borrowers and savers.

As China slowly liberalizes its capital account, it faces a key challenge of maintaining domestic monetary and price stability. ${ }^{2}$ To avoid the trilemma problem, China has allowed somewhat more exchange rate flexibility in recent years. But growing balance of payments surpluses through both the current and financial accounts have put upward pressure on the currency. To limit appreciation of the domestic currency, the renminbi (Rmb), Chinese monetary authorities have intervened in the foreign exchange market and accumulated massive amounts of foreign reserve. As a result, China’s holdings of foreign reserves have risen from $\$ 140$ billion in

\footnotetext{
${ }^{1}$ See Obstfeld, Shambaugh, and Taylor, 2005 for further discussion and references dealing with the trilemma. Related papers have raised the possibility that a pegged exchange rate is a trap in the era of greater financial integration (e.g., Eichengreen, 2001; Frankel, 1999; Edwards and Levy-Yeyati, 2005; Aizenman and Glick, 2008).

${ }^{2}$ For example, China in recent years has permitted limited expansion of portfolio capital flows through "qualified investment” programs. Moreover, unofficial flows into and out of China have grown over time.
} 
1997 (15 percent of GDP) to over \$1.5 trillion at the end of 2007 (more than 45 percent of GDP), with two-thirds of this buildup occurring in the last three years.

This reserve buildup has raised concerns about monetary and inflation stability in China, as both money aggregates and prices have grown faster. A not-so-distant memory is the excessive expansion of the monetary base, money, and credit between 1991 and 1994 - when these aggregates grew at times by over 40 percent per annum -- resulting in high inflation, with CPI rising near 30 percent at its peak. ${ }^{3}$ The current foreign reserve boom has lead to similarly large increases in the monetary base in recent quarters, threatening a return of higher inflation. In recent quarters the monetary base has grown over 30 percent and CPI inflation has risen above 8 percent. ${ }^{4}$

As long as China continues to place a higher priority on exchange rate stability than on using monetary policy as tool for macroeconomic control, China's scope for an autonomous monetary policy is constrained. Chinese monetary authorities have addressed this current challenge by more aggressive open market sterilization operations as well as by raising reserve requirement ratios and employing window guidance measures. The extent to which China will successfully confront the trilemma problem depends on achieving the right balance of policy objectives. As reserve accumulation continues, the conflict between monetary and exchange rate objectives will become increasingly harder to resolve, particularly as remaining controls on capital flow become more difficult to maintain.

In this paper we investigate the extent to which the rise in China's foreign reserves has affected the country's monetary policy and been a source of monetary instability contributing to higher inflation. We begin by characterizing the nature of China's balance of payment flows and the effectiveness of its capital controls. We find that pressure on China's exchange rate regime increased after its ascension to the World Trade Organization in 2001 and the emergence of growing current account surpluses. These surpluses, together with large long-standing inflows of foreign direct investment, have presented China's authorities with a structural imbalance in the country's balance of payments. This imbalance, combined with bouts of "hot money” capital inflows spurred by speculation on Rmb appreciation against a backdrop of greater capital account openness, has led the People’s Bank of China (PBC) to engage in ever-increasing foreign exchange market purchases and foreign asset accumulation to dampen appreciation of the currency.

\footnotetext{
${ }^{3}$ This episode was also characterized by a sharp deterioration of asset quality, resulting in substantial increases in nonperforming bank loans.

${ }^{4}$ Since much of this inflation has shown up as a sharp increase in food prices, attributable to food shortages caused by bad weather and livestock disease, some have argued that the recent inflation is not monetary in origin. Rogoff (2008) has described these alternative views as the "pork" vs. "money" debate and states that "Those who believe that the cause of China's inflation is too little pork, rather than too much money, are seriously mistaken."
} 
The second part of our analysis measures the degree to which the PBC has been able to insulate reserve money growth from the liquidity effects associated with rapid foreign asset accumulation. We present estimates of how China's marginal propensity to sterilize the effects of foreign asset accumulation on the monetary base has changed over time, rising until 2006 and then sharply declining as the authorities found it increasingly more difficult to limit the liquidity effects of massive foreign exchange asset accumulation.

The third part of our analysis addresses the broader monetary and inflationary impacts of the foreign reserve buildup. We formulate and estimate a vector error correction model (VECM) characterizing the evolution of reserve money, broad money, real GDP, and prices. Although each variable individually appears to follow a stationary process in first differences, formal cointegration tests suggest that two long-term stable relationships (co-integrating vectors) characterize the system. We interpret these co-integrating relationships as long-run money demand and money supply functions. Estimates of the VECM model, which captures both short-run dynamics and long-term relationships in the data, allow us to carry out model simulations for alternative paths of foreign reserve accumulation and sterilization. Under a scenario of rapid foreign exchange reserve accumulation, limited exchange rate flexibility, and rapid economic growth - the economic environment of recent years--the model predicts a rapid increase in inflation if sterilization continues to have limited effectiveness. An extension of the model incorporates increases in bank reserve requirements and predicts similar inflationary pressures. However, an alternative scenario with slow economic growth but continued rapid reserve money growth predicts a decline in inflation over a three year horizon.

The paper is organized as follows. Section 2 describes the pattern of balance of payments flows that underlie the surge in China's accumulation of foreign reserves. Section 3 analyzes the PBC's efforts to sterilize the effects of the reserve inflows on the conduct of monetary policy. Section 4 presents the VECM results capturing the dynamic interaction of reserve inflows and monetary control in China. This section also presents alternative monetary policy simulations. Section 5 concludes the paper.

\section{Foreign Reserve Accumulation and Capital Account Openness in China}

\subsection{Pattern of Balance of Payments Flows}

China's holdings of foreign exchange reserves have risen dramatically in recent years. Table 1 shows China's balance of payments (BOP) and pattern of reserve accumulation over the past two decades and decomposes the reserve buildup into the current account, foreign direct investment inflows, and a residual component consisting of net securities, other capital inflows, 
and errors and omissions. We interpret these non-FDI capital inflows, as "hot money" that could potentially switch direction within a short horizon. ${ }^{5}$ Figures $1 \mathrm{a}$ and $1 \mathrm{~b}$ provide a visual summary of the changes in these components unscaled and scaled by nominal GDP (converted into dollars by the average $\mathrm{Rmb} / \$$ exchange rate), respectively. Table 2 compares the average level and changes in BOP flows over different subperiods.

The increase in foreign reserves over time is associated most prominently with growing current account surpluses and FDI inflows. ${ }^{6}$ The annual current account balance rose from \$17 billion in 2001 (1.3 percent of GDP) to \$326 billion in 2007 (almost 10 percent of GDP). Direct investment inflows have grown steadily over this period, though less rapidly.

The figures also show the relative variability of non-FDI capital flows compared to the current account and FDI flows. Hot money outflows were large in the aftermath of the 1997-98 crisis, switched to inflows in 2001-04, then outflows in 2005-06, and large inflows again in 2007. More specifically, non-FDI capital inflows (including errors and omissions), swung from an average of minus $\$ 54$ billion in 1998-2000 to plus $\$ 24$ billion in 2001-04, a turnaround of \$78 billion more inflows on an annual basis (as compared to an increase in the average current account surplus by $\$ 18$ billion over the period). They then switched to an annual average of minus \$46 billion during 2005-06, before changing to \$102 billion in 2007, a remarkable swing of \$148 in additional inflows (compared to an increase of $\$ 120$ billion in the average current account balance). ${ }^{8}$

To gain further insight into the determinants of the swings in "hot money," Figures 2a and 2b present disaggregate results for the subcomponents of net securities inflows, errors and omissions, and "other" inflows (data is not available on all components before 1997). Observe that all of these subcomponents moved similarly during the aforementioned cyclical swings of overall hot money. Securities inflows, other investments, and errors and omissions rose by $\$ 7$ billion, \$43 billion, and \$28 billion, respectively, between 1998-2000 and 2001-04; and declined by \$37

\footnotetext{
${ }^{5}$ This interpretation is standard in the literature, e.g. Prasad and Wei (2005b). Ma and MacCauley (2007) suggest that hot money inflows also may occur through the current account, in the form of rising inward remittance transfers and lagging dividend and interest payments, as well under- and over-invoicing of exports and imports in years when the $\mathrm{rmb}$ is expected to appreciate.

${ }^{6}$ Note that because GDP grew so fast between 2004 and 2005, reserves as a ratio of GDP fell slightly during that period.

${ }^{7}$ These figures do not incorporate adjustments that have been suggested in order to deal with the PBC's use of foreign exchange reserves to recapitalize state banks in 2003 and 2005 (adding these in would increase the reported foreign reserve inflows), the capitalization of the CIC at the end of 2007 and into 2008, and the PBC's "encouragement" of state banks to use dollar assets to meet reserve requirements in 2007 and 2008.

${ }^{8}$ The swing in the flow of securities between 2006 and 2007 amounted to $\$ 169$ billion.
} 
billion, $\$ 7$ billion, and \$27 billion, between 2001-04 and 2005-06; and then rose by $\$ 27^{9}$ billion, $\$ 81$ billion, and $\$ 41$ billion between 2005-06 and 2007. ${ }^{10}$

These swings in hot money illustrate the sensitivity of capital flows to market considerations. The immediate post-Asia crisis period coincided with depreciation pressures on the Rmb, prompting capital outflows. The increase in money inflows during the period 2001- 04 coincided with U.S. Federal Reserve interest rate cuts beginning in January 2001, relatively stable Chinese interest rates, and expectations of an Rmb appreciation, as reflected in offshore markets for non-deliverable forwards (NDF); see Figure 3. The unpegging of the Rmb to the dollar and subsequent currency appreciation beginning in July 2005 temporarily curtailed these speculative inflows and lead to the emergence of net outflows, particularly as U.S. interest rates rose.

Subsequently, the emergence again of a positive interest differential between China and the United States combined with ongoing perceptions of an undervalued Rmb may have exacerbated the speculative movement into Rmb-denominated instruments, by essentially creating the perception of a one-way bet for investors, without an associated carrying cost.

We can gain further insights by investigating details about the subcomponents of "other" net investment flows - trade credit, loans, currencies and deposits, and “other” -- as plotted in Figures 4a and 4b. Observe that since 2001, loans and (foreign) currencies \& deposits have been the most volatile components, with both growing strongly since $2005 .^{11}$

Next we examine the evolution of gross flows of assets and liabilities of selected categories of capital flows. These details help shed some light on how capital account liberalization has affected different categories of financial transactions. Figures 5a and 5b show asset and liability movements of equity and debt securities. Observe that capital account liberalization evidently lead to sharply increased equity market inflows on the liability side in 2006, particularly as the stock market boomed, and on the outflow (asset) side, to greater holdings of foreign debt securities. This reflects limitations placed on Chinese investors in acquiring foreign stocks. Gross equity security inflows increased from $\$ 2$ billion in 2002, to \$11 billion in 2004, $\$ 20$ billion in 2005, and \$44 billion in 2006, before declining to \$31 billion in 2007. This reflects inflows attracted to China’s

\footnotetext{
${ }^{9}$ Net securities inflows increased sharply from $\$ 5$ billion in 2005 to $\$ 68$ billion in 2006, before declining to $\$ 10$ billion in 2007. This reflects inflows attracted to China's booming stock market in 2006, which fell off in 2007 as equity prices fell.

${ }^{10}$ Prasad and Wei (2005b) suggest that errors and omissions may reflect valuation changes of official foreign exchange reserves (positive when the dollar falls against major currencies, leading to an errors and omission inflow), rather than unrecorded capital inflows.

11 The interest rate differential and exchange rate expectations especially affected the evolution of Chinese foreign currency deposits (Ma and McCauley, 2002, 2003, 2007), as the share of onshore foreign currency deposits as a proportion to Rmb deposit held by Chinese households and firms in China's banking system declined during the period over the period 2002-2005 when the Rmb was expected to appreciate.
} 
stock market that was newly reformed ${ }^{12}$ in 2005 and boomed through 2006, but then fell off in 2007 as equity prices fell. Gross outflows in the form of the acquisition of foreign debt securities rose from $\$ 7$ billion in 2004, to a remarkable \$109 billion in 2006, which then fell to $\$ 20$ billion in 2007. Figures 6a, 6b, and 6c show asset and liability movements of loans, currency \&deposits, and “other” other investment flows.

\subsection{China's Capital Account Controls}

Capital controls, which prevent money from moving in an out of an economy easily, can insulate domestic monetary policy to some extent. Since the start of China's reform and open-door policies, foreign direct investment (FDI) inflows have been encouraged, while other inflows and capital outflows were initially heavily controlled. ${ }^{13}$ Non-bank Chinese residents and institutions had been prohibited from directly investing in overseas securities, though banks were permitted to invest their own dollar assets in fixed income instruments

In recent years, China has liberalized controls on non-FDI capital flows very slowly. Authorized banks were allowed to transact cross-border to accommodate onshore non-bank depositors and borrowers wishing to deposit and borrow in foreign currency. China has sought to institutionalize the management of two-way portfolio flows through programs for so-called “qualified foreign institutional investors” (QFIIs) for portfolio inflows and "qualified domestic institutional investors” (QDIIs) for portfolio outflows. ${ }^{14}$ Both programs involve pre-approval procedures, quota management, foreign exchange conversion rules, instrument restrictions, and intensive reporting requirements. With the introduction of the QDII plan in 2006, China opened an official channel for Chinese households and firms to gain access to global financial markets. Appreciation pressures on the Rmb have led China to encourage outflows through other channels, for example, by relaxing restrictions on currency conversion by domestic residents. ${ }^{15}$ In addition, firms and banks have been given flexibility to issue foreign-exchange denominated bonds in local markets and to raise their direct overseas investment.

\footnotetext{
12 The main reform was the elimination of the "overhang" from nontraded government-owned shares.

${ }^{13}$ The Rmb has been convertible for current account transactions since December 1996, when China satisfied the IMF's Article VIII criteria for membership.

${ }^{14}$ In December 2002, QFIIs were allowed to invest in A shares and other domestic securities, subject to requirements of at least $\$ 10$ billion in assets under management and prior experience. Repatriation was limited by lock-up periods on stocks of as long as one-year. New rules in September 2006 lowered the asset under management criteria to \$5 billion, reduced the lock-up period to three months, lessened experience requirements, and also raised the quotas for investment in Chinese equities. The QDII program, launched in July 2006, permitted qualified commercial banks, securities firms, and insurance companies in China to make limited offshore investments in foreign-currency denominated assets (restricted to fixed income securities in the case of banks and insurance companies).

${ }^{15}$ In 2007 the PBC raised to \$50 thousand the ceiling on the conversion between Rmb and foreign currency by Chinese individuals.
} 
Though China had tightly controlled portfolio flows and most external debts for a long time, ${ }^{16}$ there is evidence that these capital controls were leaky and had tended to become less effective over time even before the recent relaxation of capital controls. The sheer magnitude of net and gross portfolio capital and "hot money" inflows clearly casts doubt on the effectiveness of China's capital control regime. Moreover, as the evidence presented in Section 2.1 and Ma and MacCauley (2007) illustrate, despite the existence of remaining capital controls, there are many indications that China's capital account flows respond to market conditions, suggesting limits to the effectiveness of these controls. "Hot money” flows have apparently been responsive to expectations of Rmb appreciation. Similarly, foreign exchange deposits held by Chinese households and firms onshore with banks in China have tracked exchange rate expectations, rising as a share of total bank deposits when the Rmb was expected to depreciate and falling when the Rmb was expected to appreciate.

Nevertheless, although permitted cross-border flows have helped reduce the effectiveness of China's remaining capital controls, they have not been large enough to eliminate the onshore/offshore Rmb yield gaps. Sizable onshore-offshore yield gaps persist and substantial evidence analyzing the relationships between implied forward rates, interest rates. and equity prices indicate that Chinese capital controls continue to be effective in partly "decoupling” Chinese financial markets from those in the U.S., Hong Kong, and elsewhere (see Cheung et al., 2006; Ma and McCauley, 2007; and Liu and Otani, 2005).

\section{Reserve Accumulation and Sterilization}

\subsection{Central Bank Balance Sheet Implications of Reserve Accumulation}

Reserve accumulation has monetary implications for a country's monetary base. When a central bank purchases foreign reserve assets, it must decide whether to fund it by increasing the reserve money base or by reducing its net domestic assets, which sterilizes the impact on the domestic reserve money base. Countries may sterilize because of concern about the ability of the domestic banking system to intermediate and manage the extra liquidity prudentially and/or because the increased liquidity may lead over time to economic overheating and a buildup of inflation pressures.

Central banks may offset the effects of reserve accumulation on the monetary base in a number of ways, including selling domestic government securities out of its portfolio or by issuing domestic securities in its own name, e.g. central bank bills. When markets are thin, some

\footnotetext{
${ }^{16}$ Prasad and Wei (2005a) provide an extensive chronology of capital controls over the period 1980 - January 2005.
} 
authorities rely on non-market instruments, such as transferring the deposits of government and public financial institutions from the commercial banking system to the central bank or selling foreign exchange reserves to the government (perhaps to allow it to reduce external sovereign debt). ${ }^{17}$

Sterilized reserve purchases face no defined limits since the central bank can permit its net domestic assets to fall below zero by issuing new liabilities. However, sterilized reserve purchases come at a fiscal cost that depends on the difference between, on the one hand, the return paid on central bank liabilities issued to sterilize domestic liquidity (or the opportunity cost from foregone returns on domestic assets, such as government bonds, sold to the private sector) and, on the other hand, the return earned on foreign reserve assets, as well as foreign exchange risk, if the domestic currency appreciates. Thus monetary authorities that sell government bonds or central bank bills to soak up liquidity must offer increasingly higher yields to convince domestic agents to hold them.

\subsection{Reserves and Money Aggregates}

Figure 7 plots 4-quarter changes in net foreign assets and in net domestic assets of the PBC, each scaled by the reserve money stock $(R M)$ at the end of the period four quarters earlier. ${ }^{18}$ Net foreign assets are defined by taking the dollar-denominated level of reserves and adjusting them for exchange rate changes, to give a valuation-adjusted measure of changes in net foreign assets in domestic currency. ${ }^{19}$ Net domestic assets (NDA) are defined as the reserve monetary base (RM) minus net foreign assets (NFA). Positive values of net foreign asset accumulation by the central bank correspond to foreign reserve inflows. Negative values of net domestic assets correspond to reductions in domestic assets held by the monetary authorities.

China's extent of sterilization was relatively limited until the early 2000s, as the monetary impact of reserve inflows (i.e. positive levels of $\triangle N F A / R M$ ) was generally augmented by monetary stimulus from central bank acquisition of domestic assets (i.e. positive levels of $\triangle N D A / R M .{ }^{20}$ Since mid-2002, however, as China experienced sharply rising foreign reserve inflows, these inflows were accompanied by negative changes in domestic asset holdings by the

\footnotetext{
${ }^{17}$ Monetary authorities also may seek to sterilize the effects of reserve inflows, not just on the reserve money base, but also on the broader money supply by, for example, increasing compulsory reserve requirements on bank deposits. China, for example, has raised reserve requirements significantly in recent years.

${ }^{18}$ Using four-quarter changes helps to smooth the data by eliminating much of the quarter to quarter noise.

${ }^{19}$ Specifically, we define $\Delta N F A_{t}=\left(S_{L C / \$}\right)_{t}\left(R \$_{t}-R \$_{t-1}\right)-\left(F L_{t}-F L_{t-1}\right)$, where $R \$$ (IMF line 11.d), denotes the local currency price of foreign exchange, $F L$ denotes financial liabilities of the central bank (IMF line 16c), $S_{L C / \$}$ is the local currency price of the dollar, and " $\Delta$ " is the change operator. Accordingly, we define $\triangle N D A=\Delta R M-\triangle N F A$.

${ }^{20}$ The exception is the period 1993 when China sterilized the effects of foreign reserve outflows by expanding the reserve money stock by increasing domestic asset holdings.
} 
central bank), implying the reserve inflows were being sterilized. The increase in the extent of sterilization in the early 2000s implies a possible break from China's prior sterilization behavior. ${ }^{21}$

China's high private saving rates, both for household and firms, have resulted in a vast flow of liquidity into the banking system, as savers have lacked alternative investment opportunities (until reform of the stock market in 2005). ${ }^{22}$ Thus, there has been a great deal of demand for PBC bills even at relatively low interest rates. Consequently, through mid 2006 sterilization was managed primarily through the sale of PBC bills; see Figure 8.

However, the sheer magnitude of PBC issuance made it harder and harder to place these securities. As a result, since mid 2006 the PBC began to rely less on bond issuance through open market operations and more on reserve requirement increases and greater window guidance as the means to mop up excess liquidity and keep the broader money aggregates from growing excessively. Figure 9 shows the increases in reserve requirements and corresponding decline in the M2-reserve requirement multiplier. It also should be noted that, despite a number of recent increases in the required reserves ratio, the banking system as a whole still has a sizeable amount of excess reserves at the PBC; see Figure 10. The PBC has cut the rate of remuneration on excess reserves (now at 0.99 percent) in order to discourage banks from holding these excess reserves; see Figure $11 .^{23}$

How successful has the PBC been in restraining overall money aggregate growth? Figure 12 plots 4-quarter growth rates of M2 and reserve money. Observe that reserve money growth, after being "relatively" low (i.e. below 20 percent) through mid 2006, has suddenly shot up, to above 30 percent. This is consistent with the story that the monetary authorities were successful with sterilizing the effects of capital inflows on reserve money until recently, primarily through open market operations.

\footnotetext{
${ }^{21}$ Proper assessment of the pressure on China's managed float versus the dollar and the need to sterilize depends on measuring the foreign reserves held by the PBC as well as the foreign reserves that have been shifted to the balance sheets of the banking system and the China Investment Corporation (CIC), newly created in September 2007. (The foreign reserves held by the CIC are being financed by Ministry of Finance through the special issuance of foreigncurrency denominated bonds, implying that the money creation associated with the CIC's reserve holdings is effectively fully sterilized.) The foreign exchange managed by the state banks has increased as a result of the recapitalization of the China Development Bank (CDB) and the increase in the amount of foreign exchange that the state banks have borrowed from the PBC. As long as Chinese banks hold their foreign exchange offshore, the PBC foreign reserves holdings are unaffected, also lessening the need for sterilization. State-owned enterprises also have been encouraged to increase their foreign investment. See Setser (2008).

${ }^{22}$ As Prasad (2007) notes, state commercial banks have also been aggressively trying to improve their balance sheets, including meeting capital adequacy requirements set by the government, in order to attract strategic investors and undertake successful IPOs. In this context, banks have had an incentive to hold PBC bills rather than increase their lending since corporate lending carries a capital requirement of 100 percent while no capital needs to be put aside for lending to the government.

${ }^{23}$ The PBC has continued to raise the required reserve ratio through 2008. On June 7, 2008, it announced an increase of $100 \mathrm{bp}$ to 17.5 percent, the fifth increase of the year.
} 
Figure 13 plots the growth rates of M2, domestic credit, and the CPI over time. Observe that M2 and credit growth peaked in 2002-2003, receded somewhat, but have since risen again. Moreover, inflation is at its highest since its 1994 peak.

\subsection{Estimation of Sterilization Response}

We now turn to quantitatively estimating changes in the degree of sterilization. Our specification is very simple. We estimate the extent of sterilization by a simple regression of the PBC's change in net domestic assets on the change in net foreign assets, where change is measured over four quarters, and scaled by the level of the reserve money stock four quarters ago. We also include the four-quarter growth rate of nominal GDP on the righthand side to control for other explanatory variables, $Z$, that might influence the demand for money: ${ }^{24}$

$$
\Delta N D A / R M_{-4}=\alpha+\beta \Delta N F A / R M_{-4}+Z
$$

We estimate the sterilization coefficient, $\beta$, with OLS using 40-quarter rolling samples. ${ }^{25} \mathrm{~A}$ unitary coefficient, i.e. $\beta=-1$, on the variable $\triangle N F A$ / RM represents full monetary sterilization of reserve changes, while $\beta=0$ implies no sterilization. The results are plotted in Figure 3. Coefficient observations correspond to the calendar date of the $40^{\text {th }}$ quarter in each rolling sample. $^{26}$

Observe that the sterilization coefficient began rising (in absolute value) from roughly 0.6 in 2000, a trend that accelerated in the latter half of 2002 and continued into 2006 when it peaked at almost 1.5, suggesting the presence of a break in behavior. The plot also indicates a reversal of China's sterilization behavior beginning in the fourth quarter of 2006. The reduced degree of sterilization, with a point estimate approaching 0.8 (significantly less than 1.0), indicates that at least 20 percent of the growth in foreign reserves is translating into reserve money growth and that this percentage rose in 2007. This finding is also evident in Figures 7 and 8. Limited sterilization,

\footnotetext{
${ }^{24}$ We imputed quarterly GDP growth in our sample from a moving average of the prior year, current, and following year observations.

${ }^{25}$ Central bank balance sheet data for China is available only from 1985 Q3, implying that the first 4-quarter change observation begins in 1986 Q2, and the first 40-quarter rolling sample period is 1986 Q2 - 1996 Q1. We then roll the sample period to 1986 Q3 - 1996 Q2, etc., ending with 1998 Q1 - 2007 Q4.

${ }^{26}$ For clarity, we omit standard error bands. It may be stated, however, that the coefficients are always significantly different from 0 . Our estimation procedure abstracts from several econometric issues. For example, it does not taken account of possible simultaneity bias because net foreign asset changes may respond to domestic monetary policy, particularly when the central bank intervenes and affects the exchange rate. However, prior work seeking to control for the possible endogeneity of the explanatory variables in sterilization regressions through instrumental estimation has not found much effect on coefficient magnitudes and their standard errors as compared to OLS (e.g., Ouyang, Rajan, and Willett). We also abstract from any dynamics in the sterilization response. An alternative approach employed by Mohanty and Turner (2006) includes the lagged dependent variable on the righthand side, enabling estimation of short run and long run sterilization responses (though from an obviously very restricted specification; see Glick and Hutchison (2003) for an unconstrained approach to estimating sterilization dynamics).
} 
in turn, lies behind the surge in reserve money (RM) growth starting in 2006 Q4 and continuing throughout 2007.

This recent sharp decline in China's degree of sterilization can be attributed to two possibilities. First, China's foreign reserve accumulation in recent periods may be overstated to the extent that the reported figures have not been adjusted to take account of swaps and shifts of foreign reserve assets to China's nascent sovereign wealth fund. ${ }^{27}$ Second, China may indeed have reached limits to the extent of its ability to sterilize its massive reserve inflows. ${ }^{28}$

\section{Foreign Exchange Reserve Accumulation and Monetary Control}

\subsection{Background}

The previous section highlights how the boom in Chinese foreign reserve accumulation has been driven by a desire to maintain an (adjustable) pegged exchange rate against the backdrop of large current account surpluses, steady inflows of foreign direct investment and occasionally very large portfolio capital inflows. Capital controls are pervasive in China, and we have reviewed interest rate and equity price evidence indicating that they remain binding in many financial instruments and financial markets. But it is also evident that net capital flows and gross inflows and outflows of capital flows are very large and that much of these flows are circumventing official legal restrictions on capital transactions, either with the tacit approval of the government or through other channels.

Capital flows (and capital controls) and exchange rates form two parts of the trilemma. The third part is independent monetary policy. Has the People’s Bank of China (PBC) been able to maintain independent monetary control in face of foreign exchange accumulation? Has it been able to navigate the trilemma without losing course in terms its longer term monetary growth and inflation objectives?

We have presented somewhat mixed evidence on this point in the earlier sections. On the one hand, reserve money growth has jumped over the past two years in tandem with foreign exchange reserves, and broad money growth (M2) also has been growing rapidly. In response, the

\footnotetext{
${ }^{27}$ China's sovereign wealth fund, the China Investment Corporation, was not formally established until the latter half of 2007 with an initial capitalization of $\$ 200$ billion out of China's total reserve holdings of more than $\$ 1.3$ trillion. But there are indications of central bank asset shifts to its predecessor institution, Huijins Investment, and to some Chinese commercial banks before then. Netting these amounts against reported foreign reserve holdings would reduce the magnitude of foreign reserve inflows and raise the implied level of central bank domestic assets, resulting in a lower estimated degree of sterilization. Thus, as Setser (2008) points out, China has continued to add to its foreign assets, but less of the increase is showing up in formal reserves.

${ }^{28}$ Aizenman and Glick (2008b) report formal regressions assessing the significance of breaks in China's (and other emerging market economies) sterilization behavior. Their methodology identifies an increase in sterilization for China beginning in 2002 Q2, supporting the rolling regression result that sterilization behavior intensified over the period 2002 Q2 to early 2006. They also report a sharp decline in China’s degree of sterilization in late 2006 and 2007.
} 
PBC has tightened bank reserve and lending requirements in an attempt to decouple the link between reserve money growth and broad money growth, where the latter is more closely linked to overall spending growth and inflation. On the other hand, our estimates of the sterilization coefficients suggest that, until quite recently, the PBC has effectively offset the rise in foreign assets on its balance sheet by corresponding reductions in domestic assets. In addition, increasing bank reserve requirements have reduced the extent to which reserve money growth has led to broad money growth. These two factors suggest that the PBC has maintained monetary control. On the other hand, temporal instability in the sterilization coefficient, together with the surge in reserve money growth (to over 30 percent in the second half of 2007 on a year over year basis) and the PBC's recent implementation of other measures to control broad money growth, suggest that the sheer magnitude of foreign exchange reserve accumulation has been difficult to manage and is compromising monetary control.

In this light, an additional issue is that the conventional estimates of sterilization coefficients, including those reported above, are only partial equilibrium estimates of central bank behavior and assume the main instrument of domestic monetary control on the central bank balance sheet is domestic asset sales and purchases. A central bank may manage monetary control primarily through foreign exchange operations rather than domestic assets, indicating that there is no sterilization, but still maintain monetary control. For operational purposes, increases (decreases) in the monetary base may be entirely controlled by foreign reserve purchases (sales) without compromising domestic monetary control.

\subsection{Model Specification}

To address this issue, in this section we estimate a vector error correction model (VECM) of the Chinese monetary sector, with the objective of judging the effects of foreign reserve accumulation-working through reserve money growth-- on monetary control and inflation. We postulate a four equation dynamic system involving broad money (M2), reserve money (RM), consumer price level (CPI) and real GDP (RGDP) as endogenous variables. ${ }^{29}$ The VECM system is estimated in log first-differences with quarterly data, four lags and seasonal dummy variables, over the 1992 Q1 - 2007 Q4 period with quarterly data.

More specifically, our model is the standard reduced rank Gaussian VAR (Johansen, 1991):

\footnotetext{
${ }^{29}$ Foreign exchange assets are not included in the system since our preliminary statistical work shows that sterilization coefficients vary over time, partly in response to a time-varying policy responses, and this would lead to instability in the co-integrating relationships. Our strategy is to investigate model simulations under alternative paths of foreign reserve accumulation and sterilization from which we are able to derive a path of reserve money growth.
} 


$$
Y_{t}=d_{t}+X_{t}, \quad X_{t}=\sum_{i=1}^{4} \Pi_{i} X_{t-i}+\varepsilon_{t}
$$

which is equivalent to

$$
\Delta X_{t}=\Pi X_{t-1}+\sum_{i=1}^{3} \Phi_{i} \Delta X_{t-1}+\Gamma d_{t}+\varepsilon_{t}, \quad \Pi=-I_{4}+\sum_{i=1}^{4} \Pi_{i}
$$

or

$$
\Delta X_{t}=\alpha \beta^{\prime} X_{t-1}+\sum_{i=1}^{3} \Phi_{i} \Delta X_{t-1}+\Gamma d_{t}+\varepsilon_{t}
$$

where $Y$ is the vector consisting of deterministic $(d)$ and endogenous $(X)$ variables (RGDP, CPI, M2, RM). The deterministic variables are intercept constants and three quarterly seasonal dummy variables.

This is a four-dimensional vector process and the unit root tests, shown in Table 3, indicate that each of the endogenous variable series contains a single unit root or is well approximated by an I(1) process. The Johanson co-integration tests can not reject one or at most two co-integrating vectors (see Table 4), indicating that two linear combinations of the variables in (log) level values are stationary.

Given these preliminaries, we estimate a VECM model with two lags and with two cointegrating vectors, one representing a long-run money demand (velocity) relationship between M2, CPI and RGDP, and the second representing a monetary control/supply link between RM and M2; the results are reported in Table 5. In the money demand equation, we estimate a value of 0.44 for price elasticity of money demand. We impose a coefficient restriction of 1.8 on the RGDP coefficient in the money demand co-integrating vector, representing the long-run income elasticity of money demand. ${ }^{30}$ In the money supply equation, we estimate a value of 1.2 for the long-run elasticity of broad money (M2) to changes in reserve money (RM), indicating that changes in reserve requirements, banking lending restrictions and so on may change the short-run response of M2 to RM, but in the longer term M2 eventually responds very substantially to increases in the reserve money. We report the cointegrating vector and VECM dynamic coefficients, as well as the key statistical properties, in Table 5. We do not report the deterministic variables (intercept constant and seasonal dummy terms) in the VECM equations for brevity.

\footnotetext{
${ }^{30}$ This coefficient is taken from Gerlach and Kong (2005). They estimate a long-run money demand function using co-integration methodology over the period 1980-2004. We did not have access to data for this length of time and found estimating this coefficient over a shorter sample to be problematic.
} 


\subsection{Simulation Exercises}

We estimate the model through 2007 Q4 and do out-of-sample simulations from 2008 Q1 to 2010 Q4 based on the assumption that the extent to which foreign reserve accumulation translates into reserve money growth continues and two alternative assumptions of real GDP growth (growth contimues at 10 percent and growth slows sharply to 5 percent). Given alternative paths of output growth and reserve money growth, we are able to obtain model-consistent forecasts of the implied broad money growth and CPI inflation rates over the simulation period. Specially, we consider two scenarios:

\section{Scenario 1: Continuation of current economic pattern}

Foreign reserves continue to accumulate at a high rate, leading to 30 percent annual growth in reserve money over forecast period. Real GDP grows at 10 percent annually over the forecast period. We calculate the implications for M2 growth and CPI inflation.

\section{Scenario 2: Growth slowdown combined with continued foreign reserve growth}

Foreign reserves continue to accumulate at a high rate and lead to 30 percent annual growth in reserve money over the forecast period. Real GDP growth drops to 5 percent annually over the forecast period. We calculate the implications for M2 growth and CPI inflation.

\subsection{Simulation Results}

The simulation results are given in Figure 15.

Scenario 1 assumes a continuation of current economic trends with high reserve money growth (30 percent) and high output growth (10 percent). As shown in the panels on the lefthand side of Figure 15, the implication of this path, given the estimated model, is that broad money growth and inflation will continue to rise sharply. The model simulations suggest that money growth rises continuously over 2008-10, reaching almost 26 percent by the end of 2010 and then stabilizing. CPI inflation follows a similar path, rising from 6.8 percent in 2007 Q4 to about 13 percent by the end of 2010. The recent rise in inflation is not temporary in this scenario, and is likely to go much higher, if the growth of international reserves continues and translates into high reserve money growth, i.e. sterilization is limited as it was during 2006 Q4 - 2007 Q4.

Scenario 2, as illustrated on the right side Figure 15, assumes a slowdown in real GDP -- to 5 percent annually over 2008-2010 - and that reserve money growth continues at a 30 percent annual rate, fueled by the unsterilized accumulation of international reserves. The model predicts, under this scenario, that broad money growth would continue to climb sharply through 2008, peaking at 21 percent, and then declines sharply over 2009-10. CPI inflation follows a similar pattern, rising through 2008, peaking at around 8 percent, and then gradually declining, reaching 3 
percent by the end of 2010. The dynamic structure of the model indicates that the fall in real GDP growth takes more than a year to translate into a decline in broad money growth and inflation.

In summary, under scenario 1 involving rapid foreign exchange reserve accumulation and limited exchange rate flexibility, the model predicts a rapid increase in inflation if sterilization continues to have limited effectiveness. However, a sharp slowdown in output growth (and continued rapid base money growth) eventually leads to a large decline in inflation.

\subsection{Simulation Result with Adjusted Money Base Growth}

In July 2006 the People’s Bank of China began to increase bank reserve requirement rates (reserves as a percentage of bank deposits). Reserve requirement rates rose from 7.5 to 16 percent by the end of 2007 and even higher in 2008. ${ }^{31}$ By withdrawing reserves available for money creation, these rate increases effectively reduced the money /monetary base ratio. ${ }^{32}$ Similar to sterilization of foreign exchange reserve increases, increasing bank reserve requirements is another method of slowing broad monetary expansion. As shown in Appendix table 1, the growth of the adjusted reserve money (i.e. "effective” reserve money that takes into account the effects of reserve requirement changes) is much lower than that of the unadjusted series. In the appendix we also report the results of two additional simulations using adjusted reserve money growth. We estimate a VECM model with simulations analogous to those reported in section 4.4, but now using adjusted monetary base.

Scenario 1A assumes high GDP growth (10 percent) and a continuation of the recent trend of adjusted reserve money growth. (Adjusted reserve money grew 7 percent annually over 2006 Q2-2008 Q1..) Scenario 2A presumes a sharp slowdown in real output (to 5 percent) along with a continuation of the same reserve money growth trend. Cointegration diagnostics are reported in Appendix tables 1 and 2; the simulation results are plotted in Appendix figure 2.

The basic results are the same as those previously reported in section 4.4. In the first scenario, inflation increases throughout the simulation period, indicating that even the rise in reserve requirements does not completely dampen inflationary pressures. Moreover, it is noteworthy that for this policy to work the central bank must continuously raise reserve requirements — otherwise the growth rates of the adjusted and unadjusted reserve money will converge. The PBOC in fact did continuously raise reserve requirements from mid-2006 through 2007 and into 2008. However, it is unclear what the limits are to such a policy, as higher reserve

\footnotetext{
${ }^{31}$ Reserve requirements peaked at $17.5 \%$ in September 2008, when the PBOC began reducing reserve requirements in response to an economic growth slowdown related to the global financial crisis..

${ }^{32}$ The adjusted series subtract out the reserve holdings calculated against the deposit base of banks that is associated with requirements above $7.5 \%$, the rate prior to July 2006 when the PBOC began raising rates. The data were kindly provided by Dong He at the Hong Kong Institute for Monetary Research.
} 
requirements act as a tax on banks and distort the financial intermediation process. The fact that four state-owed banks in China dominate a large part of the financial system suggests that a higher tax on the banking sector, via higher reserve requirements, may be pushed higher than in a more competitive financial system. ${ }^{33}$ At some point, however, one expects limitations on the ability of the central bank to distort the behavior of banks (even state-owned banks). The growth slowdown being experienced by China in 2008 indeed may contribute to declining inflation, but without a fundamental policy shift, inflation is likely to return as long as foreign reserve inflows continue.

\section{Conclusion}

In recent years China has faced an increasing trilemma-attempting to pursue an independent monetary policy and limiting exchange rate flexibility, while at the same time facing large and growing international capital flows. We argue that China's current account surpluses and foreign direct investment inflows, and occasionally large non-FDI capital inflows, combined with the objective of limiting exchange rate appreciation, have the potential to compromise China's monetary policy goal of limiting inflation.

China has sought to insulate its reserve money from the effects of balance of payments inflows by sterilizing via the issuance of central bank liabilities. However, our empirical results indicate that sterilization dropped precipitously in 2006 in the face of the ongoing massive buildup of international reserves, leading to a surge in reserve money growth. Moreover, the central bank has raised bank reserve requirements and imposed lending restrictions in an attempt to decouple reserve money growth from broad money growth. To investigate these broader implications of the trilemma for Chinese inflation, we estimate a vector error correction model linking foreign exchange reserve accumulation to developments in China's reserve money, broad money, real GDP and price level. We employ the model to explore the inflationary implications of different policy scenarios. Under a scenario of rapid foreign exchange reserve accumulation and limited exchange rate flexibility, the model predicts a rapid increase in inflation if sterilization continues to have limited effectiveness. Increasing reserve requirements has a temporary effect in dampening inflationary pressures, but even in this environment inflation eventually rises. Only in the scenario of a sharp decline in economic activity is the trilemma not binding and would inflation rates be expected to decline.

\footnotetext{
${ }^{33}$ Three of these banks were recently privatized by allowing independent minority stakes by foreign investors and by issuing publically traded equity shares. However, there is every reason to believe that the government's ability to apply moral suasion on these banks remains high.
} 


\section{References}

Aizenman, Joshua and Reuven Glick. (2008a) "Pegged Exchange Rate Regimes, A Trap?" Journal of Money, Credit and Banking, June.

Aizenman, Joshua and Reuven Glick. (2008b). "Sterilization, Monetary Policy, and Global Financial Integration,” NBER No. 13902.

Bouvatier, Vincent. (2006). "Hot Money Inflows in China!: How the People’s Bank of China Took up the Challenge,” Centre d’Economie de la Sorbonne, UMR 8174, Université Paris, Nov. 2006

Cavoli, Tony and Ramkishen Rajan. (2005). "The Capital Inflows Problem in Selected Asian Economies in the 1990s Revisited: The Role of Monetary Sterilization,” National University Of Singapore, Singapore Centre for Applied and Policy Economics, December.

Cheung, Yin-Wong, Dickson Tam and Matthew S. Yiu (2006). "Does the Chinese Interest Rate Follow the U.S. Rate?” Hong Kong Institute for Monetary Research Working Paper No. 19/2006 (December).

Edwards, Sebastian and Eduardo Levy Yeyati. (2005). "Flexible Exchange Rates as Shock Absorbers,” European Economic Review 49, 8, 2079-2105

Eichengreen, Barry. (1999). "Kicking the Habit: Moving from Pegged Rates to Greater Exchange Rate Flexibility.” Economic Journal, March, C1-C14.

Frankel, Jeffrey. (1999). “No Single Currency Regime is Right for all Countries or at all Times,” NBER Working Paper 7338, September.

Gerlach, Stefan and Janet Kong. (2005). “Money and Inflation In China,” Hong Kong Institute for Monetary Research Memorandum No. 04/2005, March.

Glick, Reuven and Michael M. Hutchison. (2000). "Foreign Reserve and Money Dynamics with Asset Portfolio Adjustment: International Evidence,” Journal of International Financial Markets, Institutions and Money 10, 229-247.

Green, Stephen., 2005. “Making Monetary Policy Work in China: A Report from the Money Market Front Line. Stanford Center for International Development, Working Paper 245.

Johansen, S. (1991). "Estimation and Hypothesis Testing of Cointegration Vectors in Gaussian Vector Autoregressive Models.” Econometrica, 59, 1551-1580.

Liu, Li-Gang and Ichiro Otani (2005). “Capital Controls and Interest Rate Parity: Evidences from China, 1999-2004.” Draft working paper, Hong Kong Monetary Authority.

Ma, G., and Robert McCauley. (2002). Rising Foreign Currency Liquidity of Banks in China. BIS Quarterly Review, September 2002.

Ma, G., and Robert McCauley. (2003). “Opening China s Capital Account amid Ample Dollar Liquidity,” BIS Papers 15

Ma, G. and Robert MacCauley. (2007). “Do China’s Capital Controls Still Bind? Implications for Monetary Autonomy and Capital Liberalization, BIS Working Paper 233, August 2007.

Mohanty, M.S. and Philip Turner. (2006). "Foreign Exchange Reserve Accumulation in Emerging Markets: What are the Domestic Implications? BIS Quarterly Review, September 2006 
Obstfeld, M., J. C. Shambaugh and A. M. Taylor. (2005). 'The Trilemma in History: Tradeoffs Among Exchange Rates, Monetary Policies, and Capital Mobility,' Review of Economics and Statistics 3, 423-438.

Ouyang, Alice, Ramkishen Rajan, and Thomas Willett. (2006). "China as a Reserve Sink: The Evidence from Offset and Sterilization Coefficients,” October.

Pazad, Eswar and Shang-Jin Wei. (2005a). "Understanding the Structure of Cross Border Capital Flows: The Case of China.” Mimeo.

Prasad, Eswar and Shang-Jin Wei. (2005b). “The Chinese Approach to Capital Inflows: Patterns and Possible Explanations.” NBER Working Paper 11306.

Prasad, Eswar. (2007). "Monetary Policy Independence, the Currency Regime, and the Capital Account in China.” Paper presented at the Conference on China's Exchange Rate Policy. Peterson Institute for International Economics, October 19.

Setser, Brian. (2008). "What to Do with over a Half a Trillion a Year? Understanding the Changes in the Management of China’s Foreign Assets,” Council on Foreign Relations, January 15.

Rogoff, Kenneth. (2008). “What if China Sputters?” Financial Times, February 4.

World Economic Outlook. (2007). “Managing Large Capital Inflows,” Chapter 3, October 2007. International Monetary Fund. 
Navigating the Trilemma: Capital Flows and Monetary Policy in China Figures and Tables

Figure 1a.

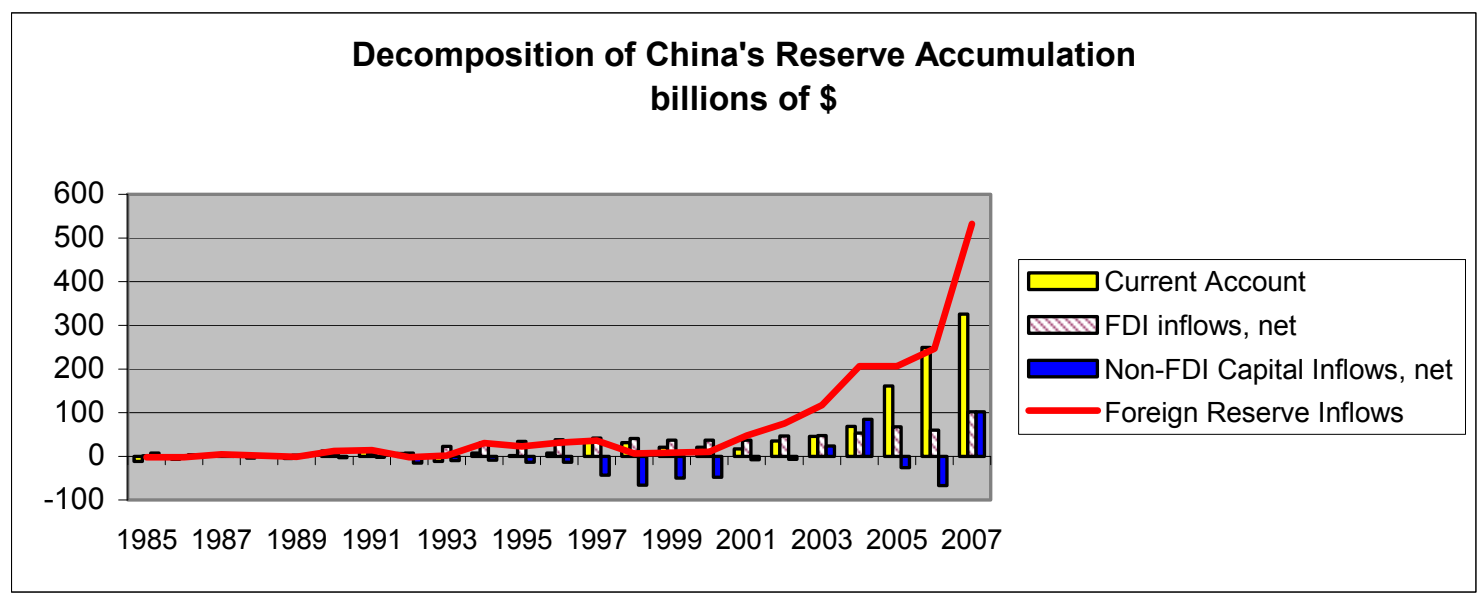

Figure 1b.

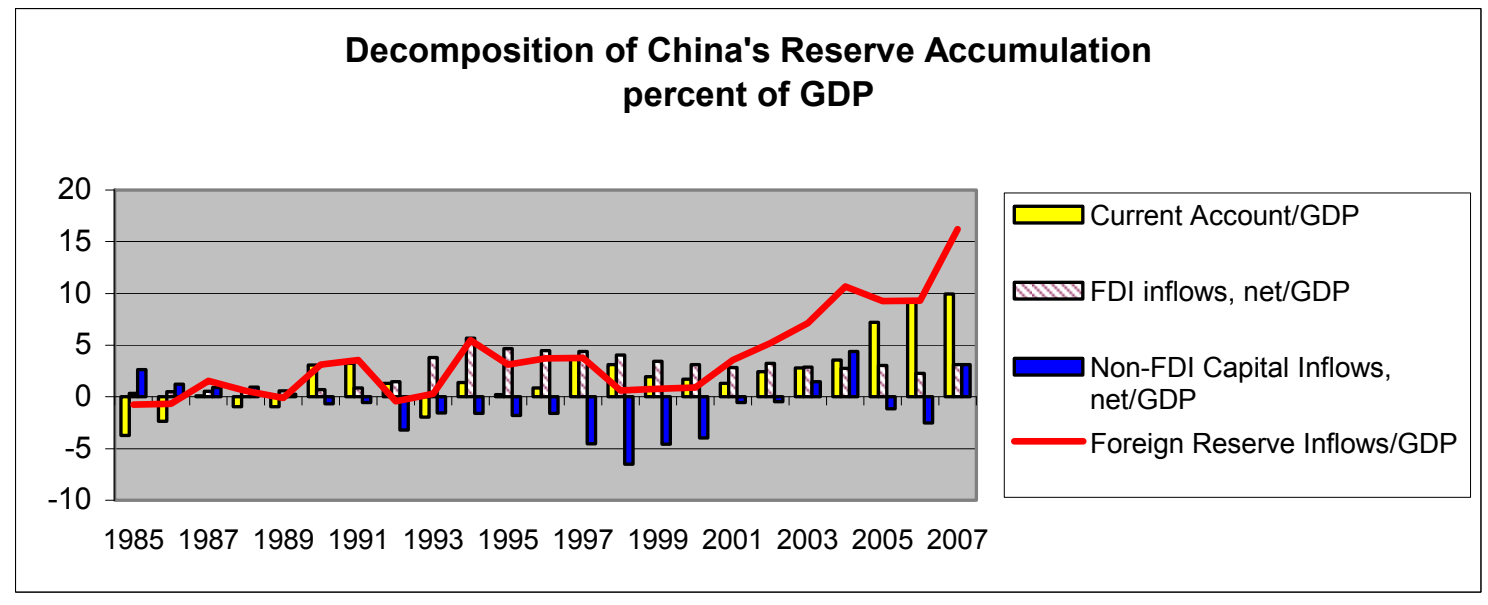


Figure 2a.

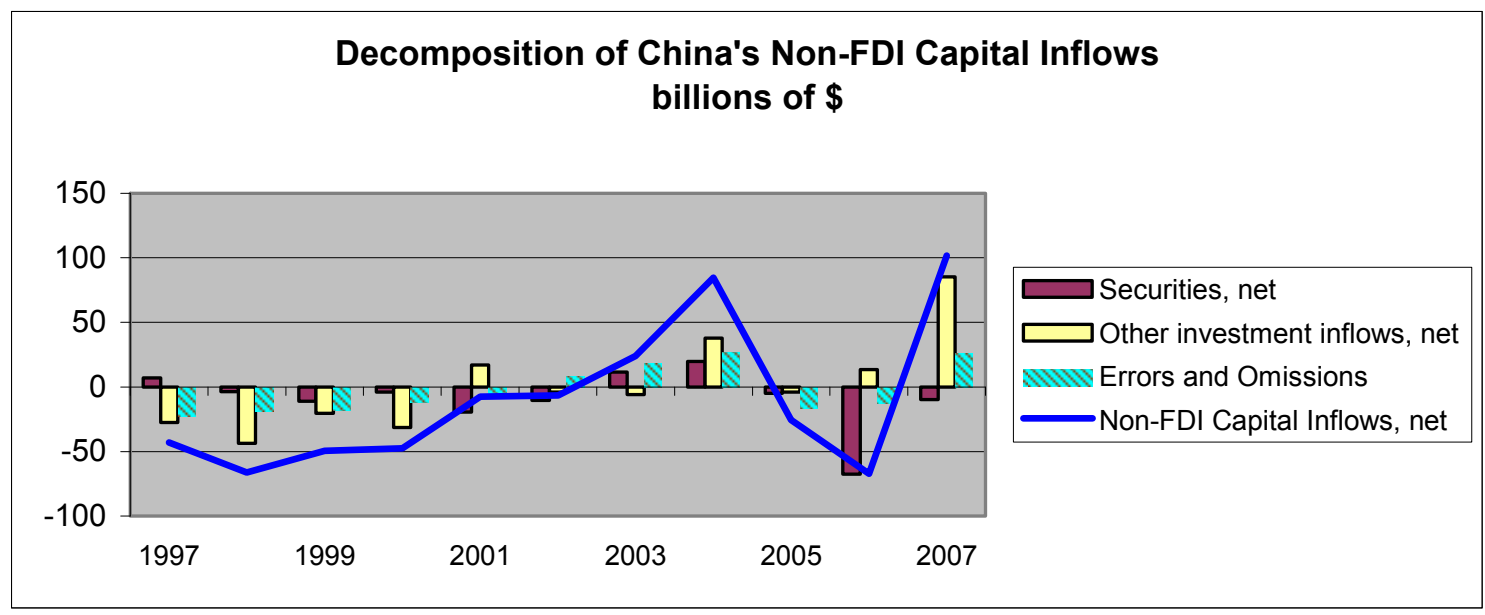

Figure 2b.

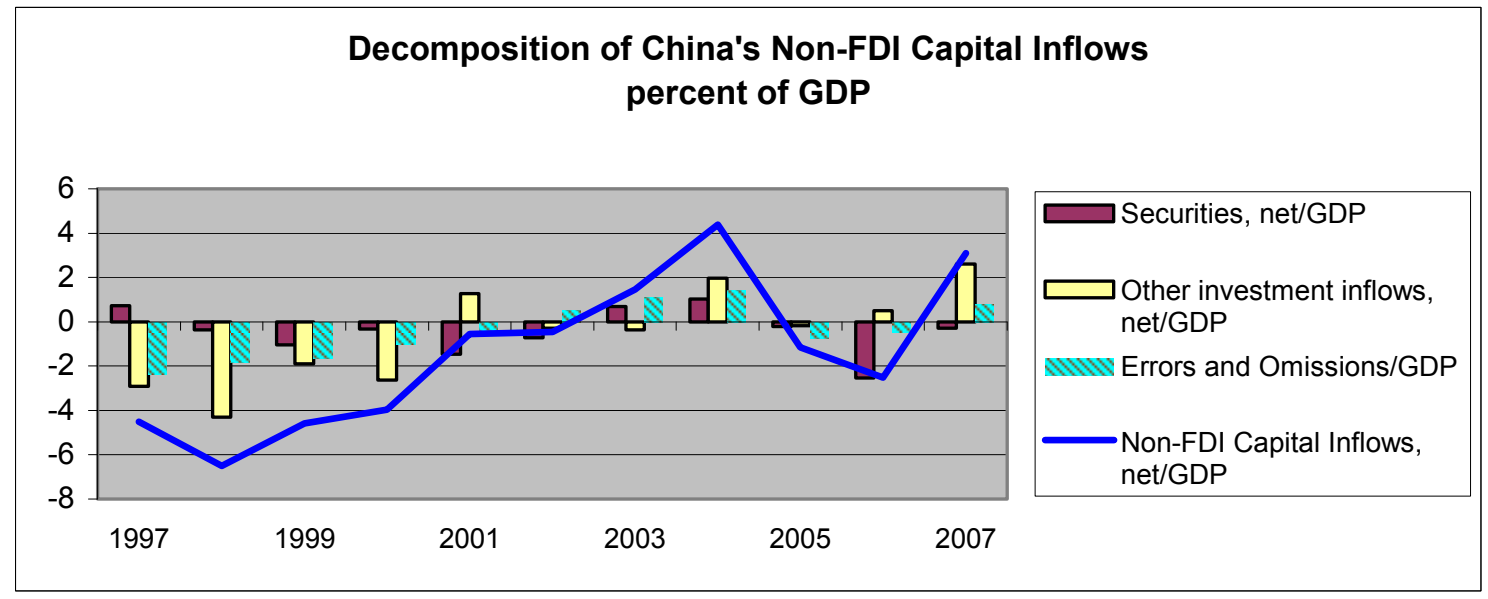


Figure 3.

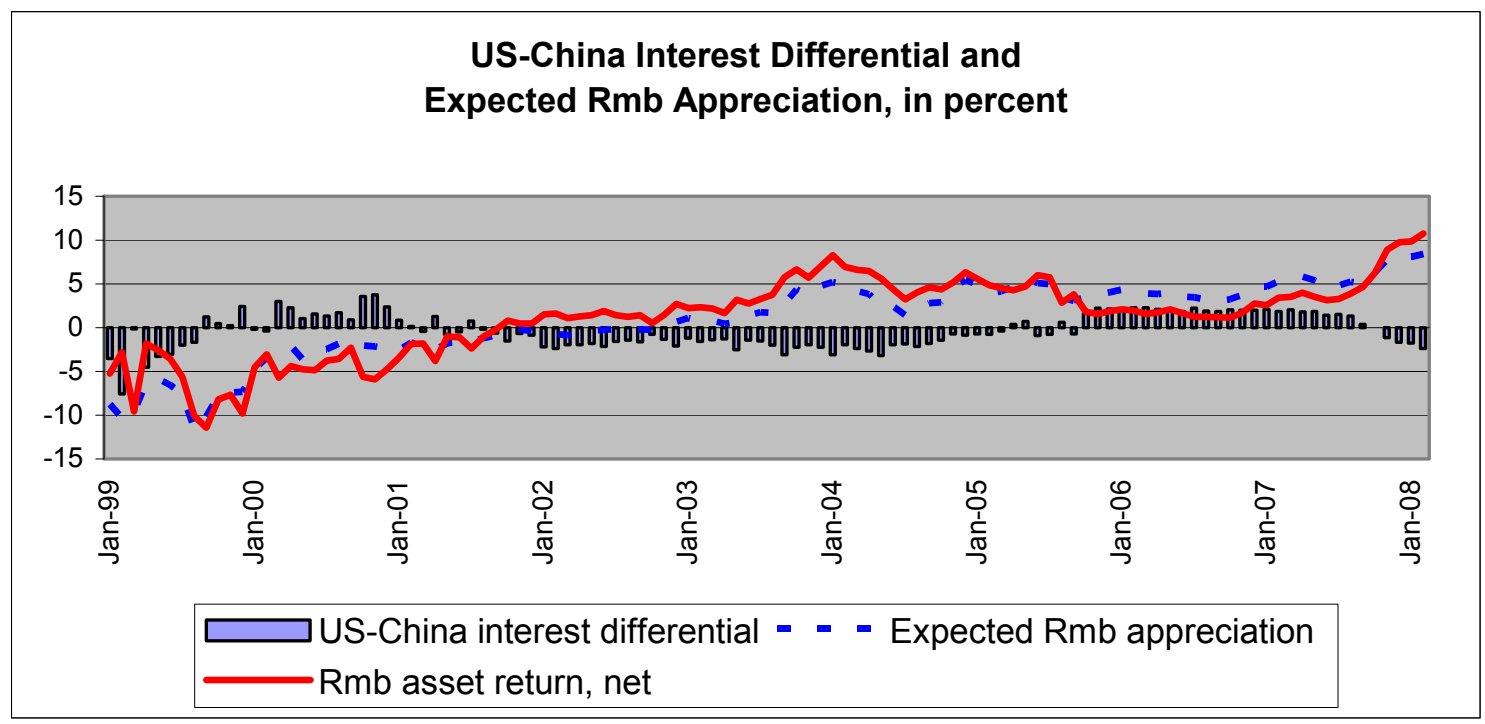

Note: positive values of "expected Rmb appreciation" correspond to a rise in the $\$ / \mathrm{Rmb}$ rate. The total net asset return to holding Rmb equals the expected appreciation of the rmb minus the U.S.-China interest differential. Thus the incentive for capital to flow into Rmb assets was highest when (i) the yuan was expected to appreciate and (ii) the U.S.-China differential was negative, as was the case during the period 2004-mid-2005 and more recently, from the latter part of 2007. 
Figure 4a.

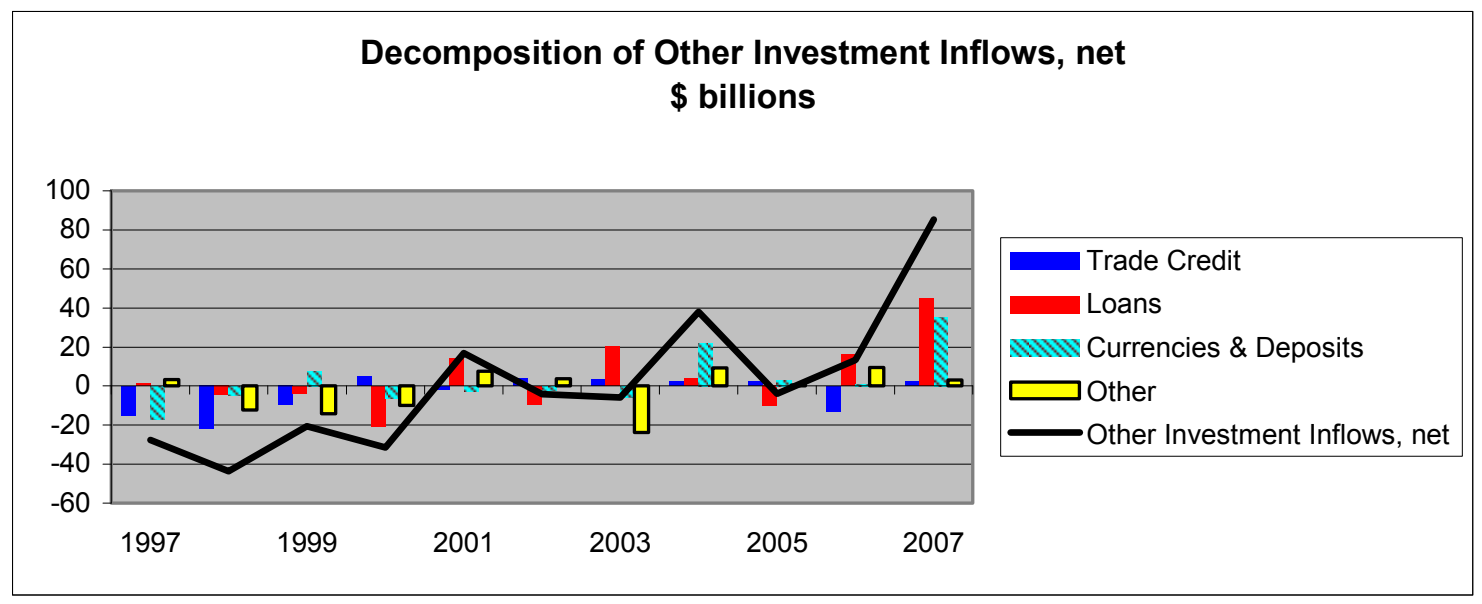

Figure 4b.

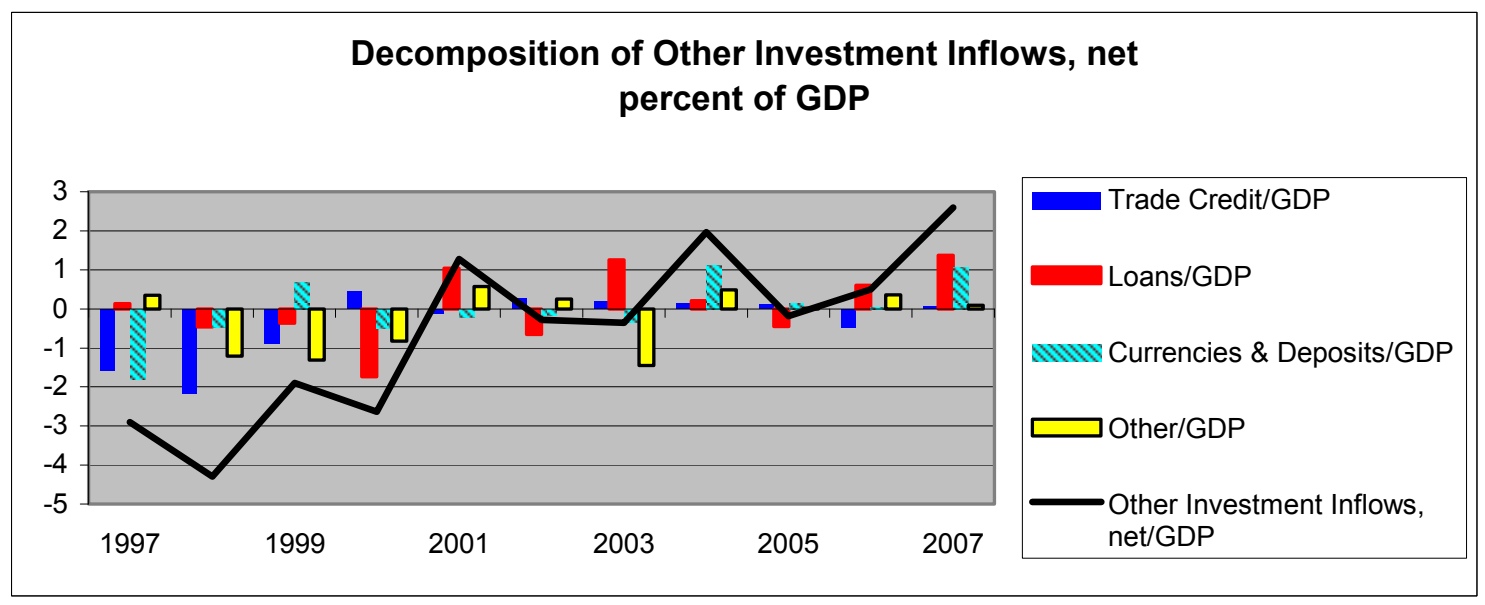


Figure 5a.

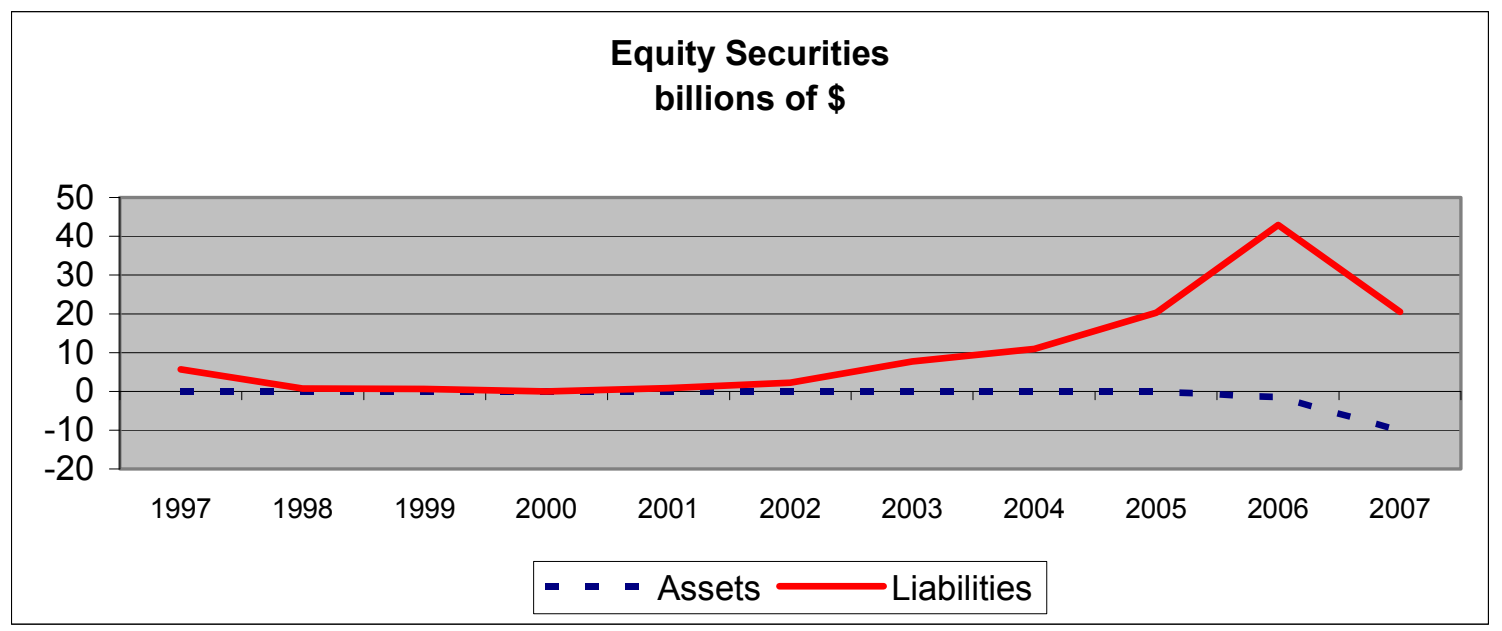

Figure 5b.

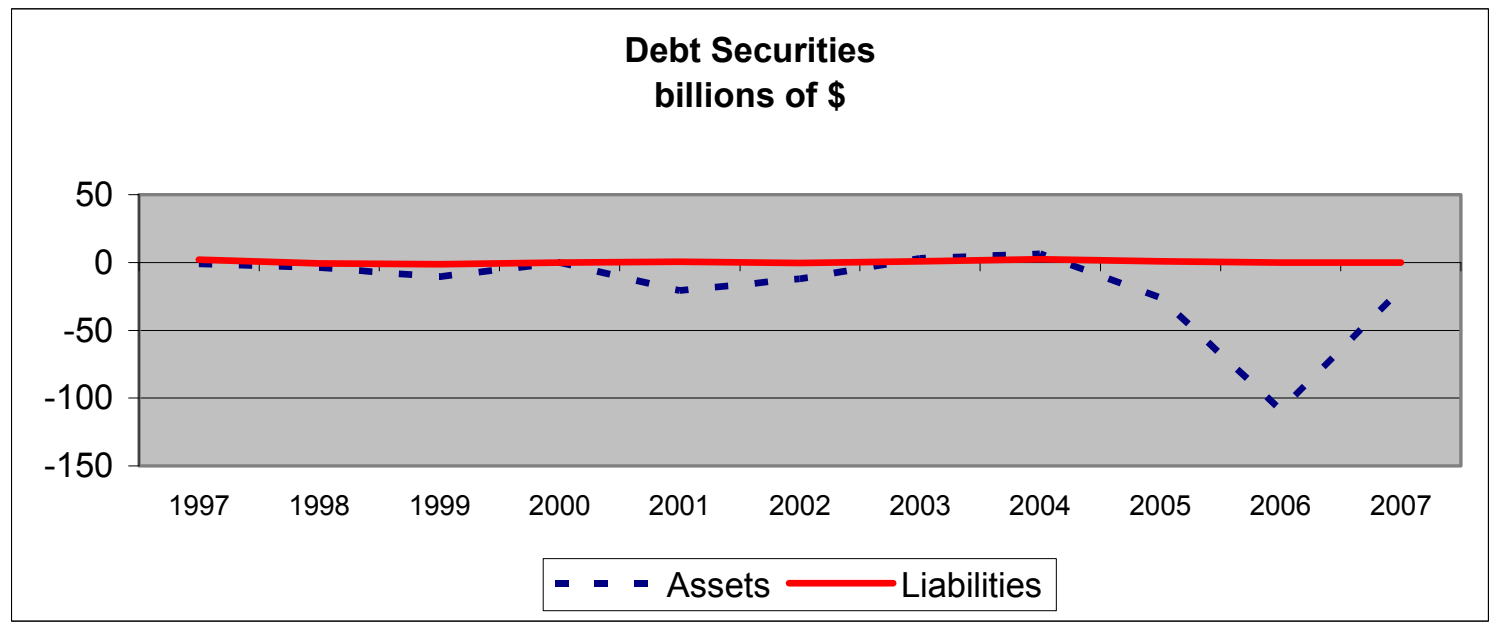


Figure 6a.

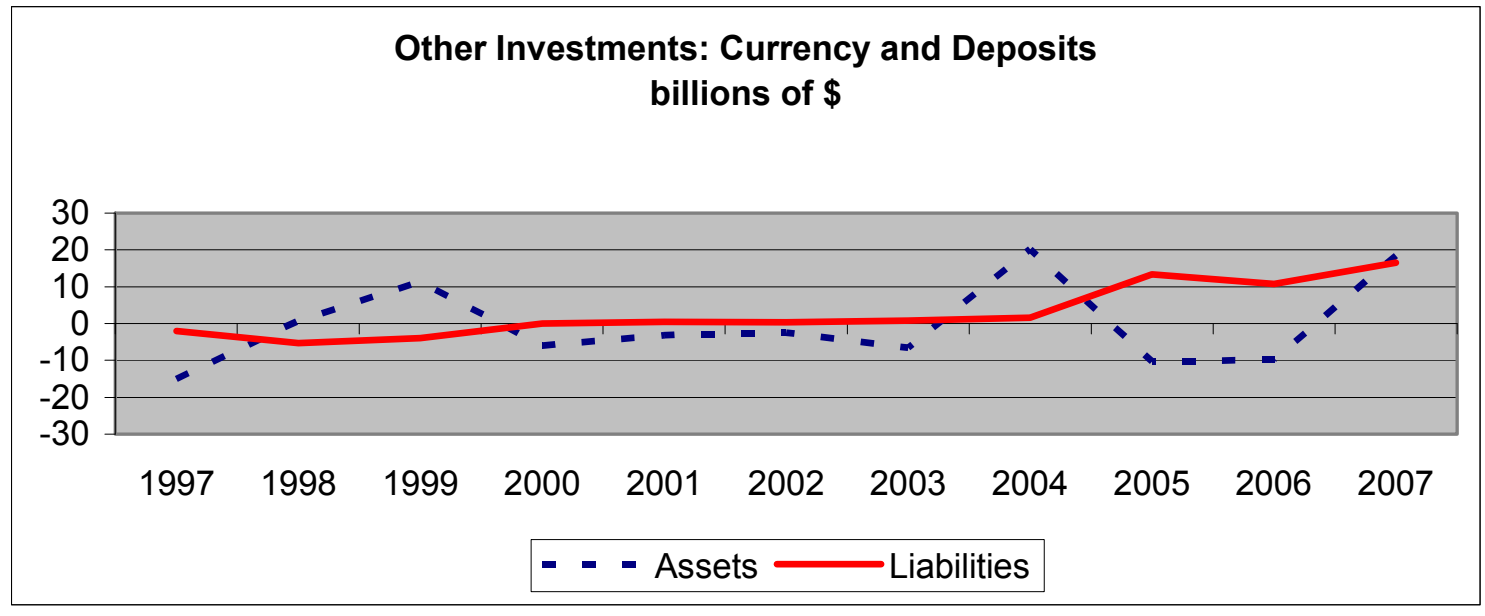

Figure 6b.

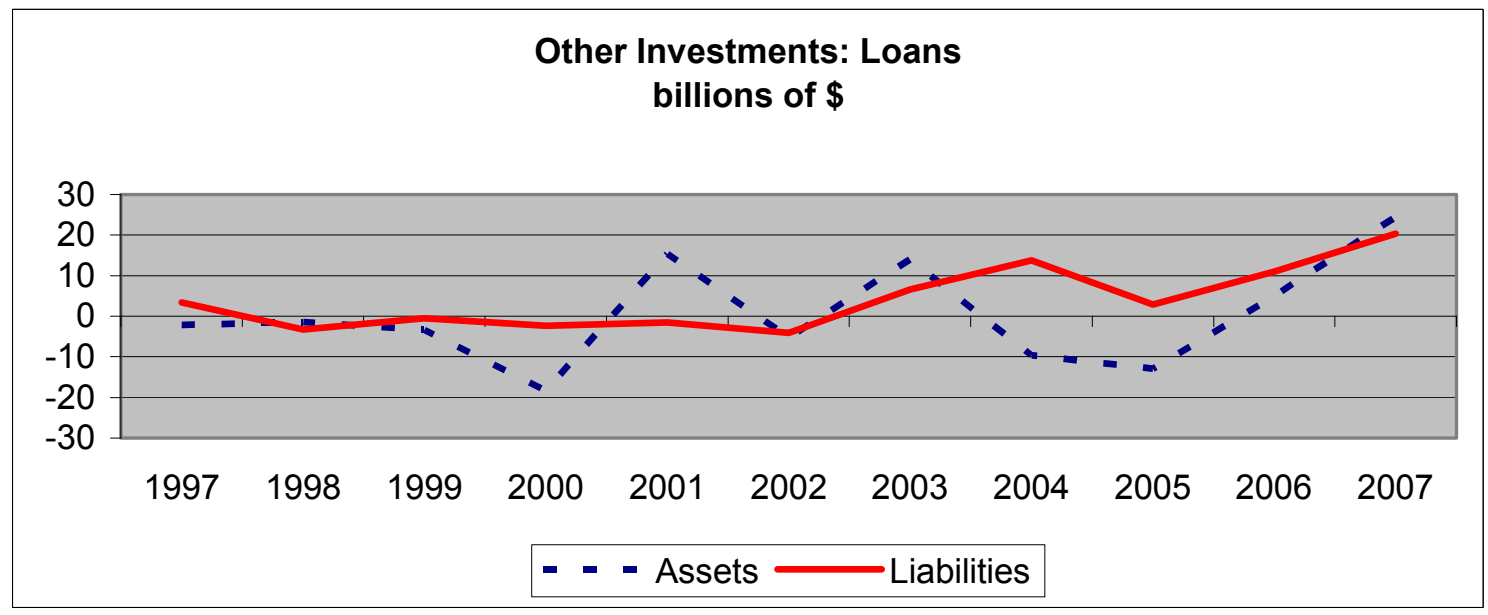

Figure 6c.

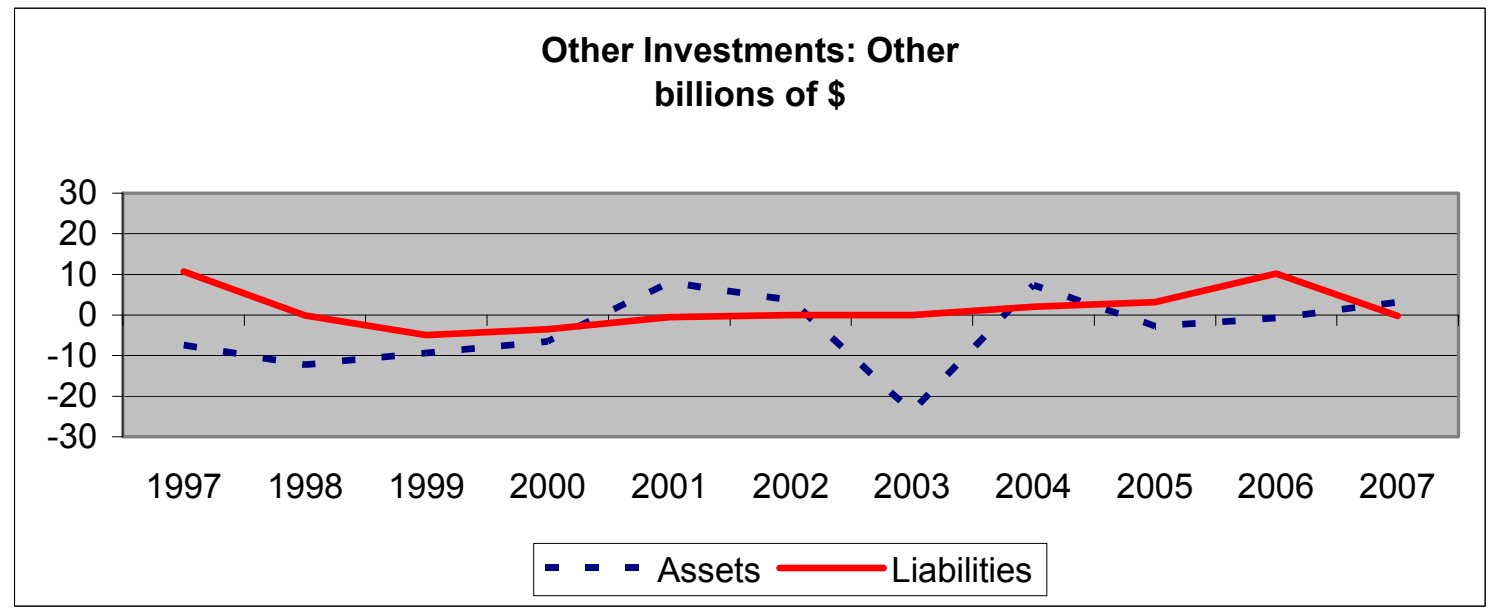


Figure 7. Net Foreign Asset and Net Domestic Asset Changes of Central Bank, (4 quarter changes relative to stock of reserve money lagged 4Q, in percent)

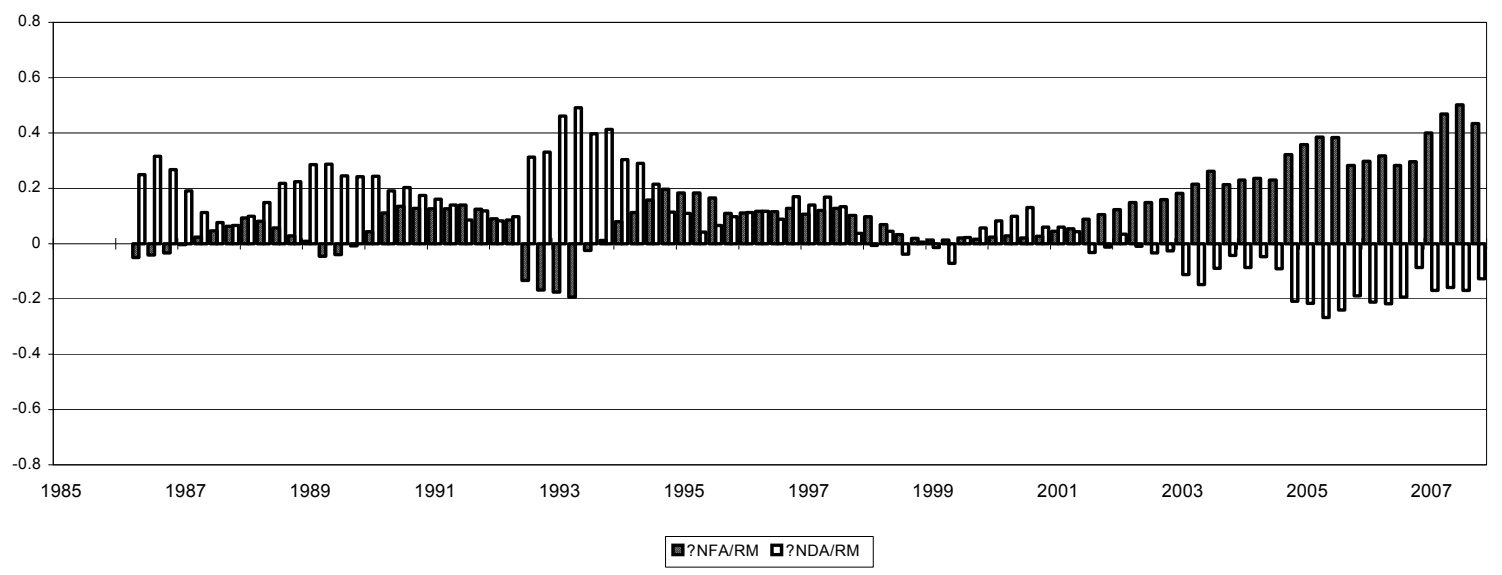

Note: positive values correspond to foreign reserve inflows or domestic asset increases.

Figure 8.

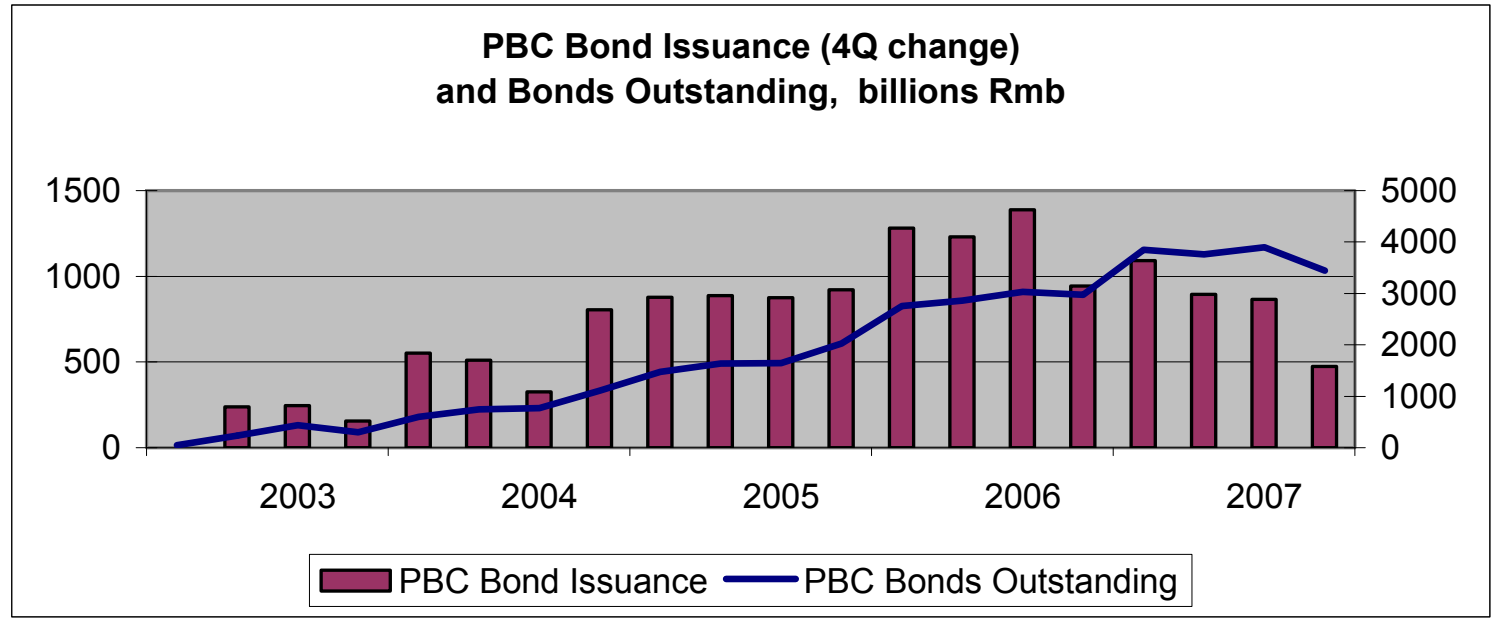

Figure 9.

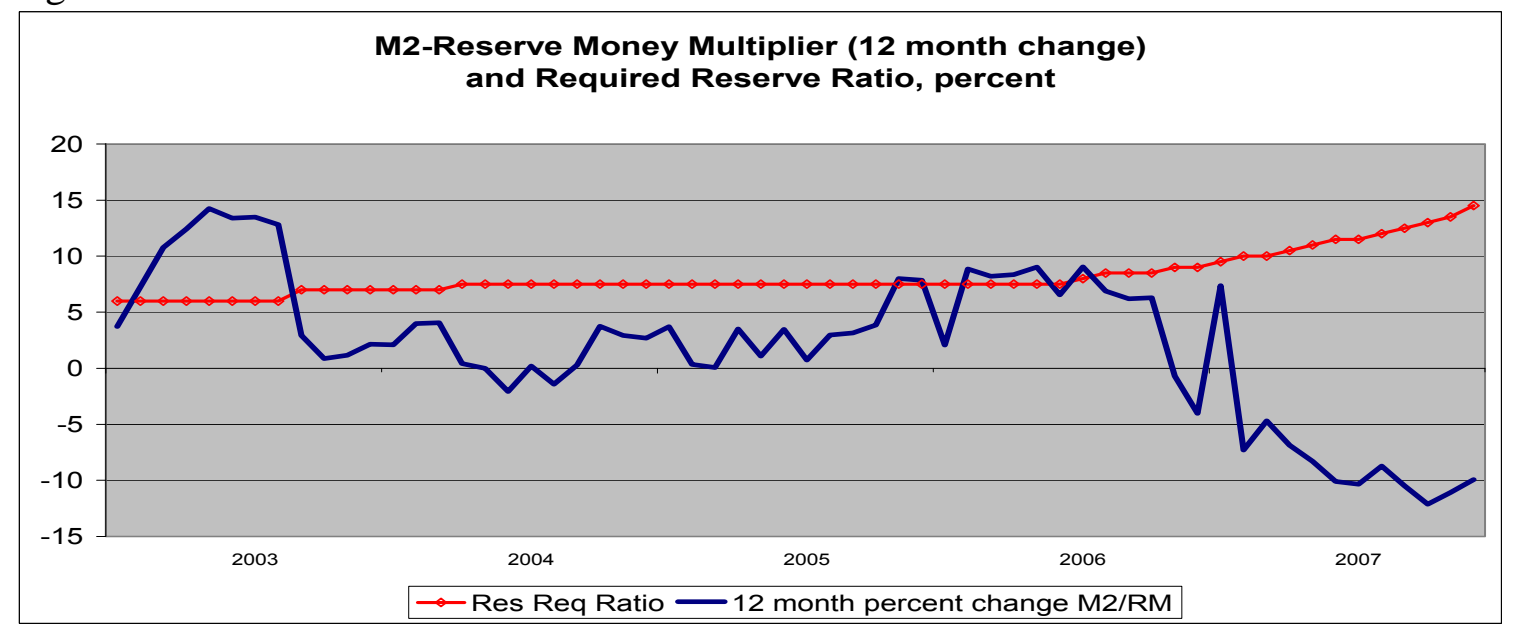


Figure 10.

\section{Interest Rates on Reserves and Repos, percent}

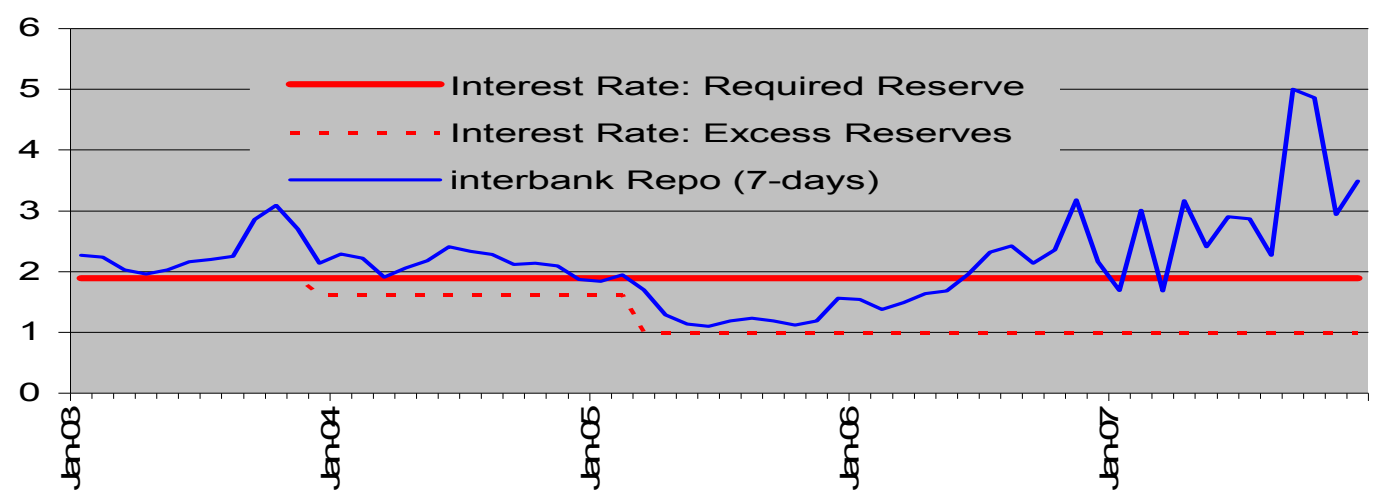

Figure 11.

Bank Reserve Ratios, percent

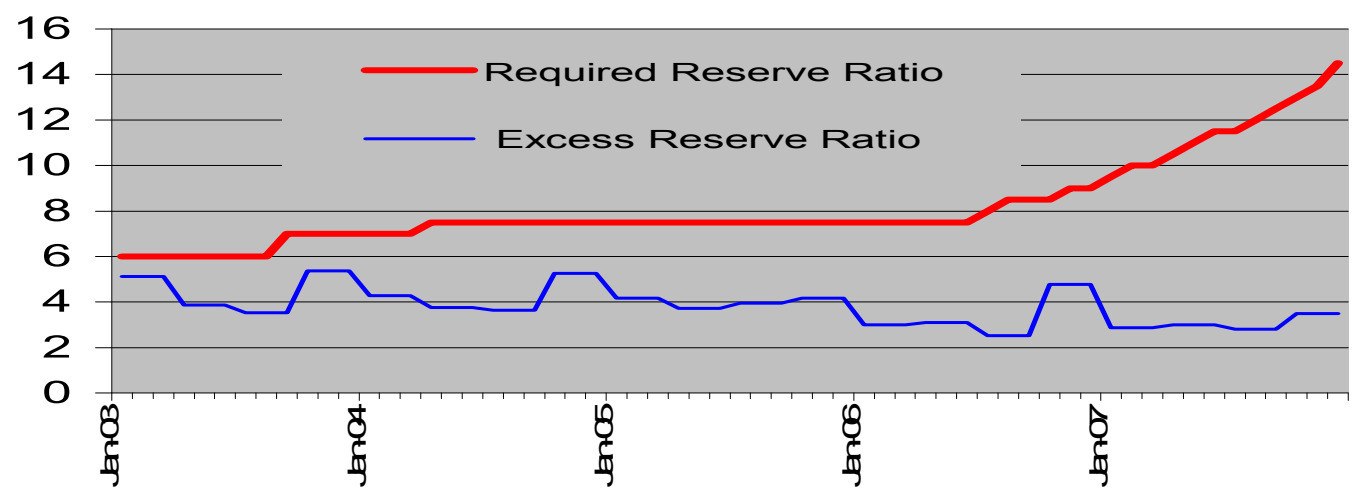


Figure 12.

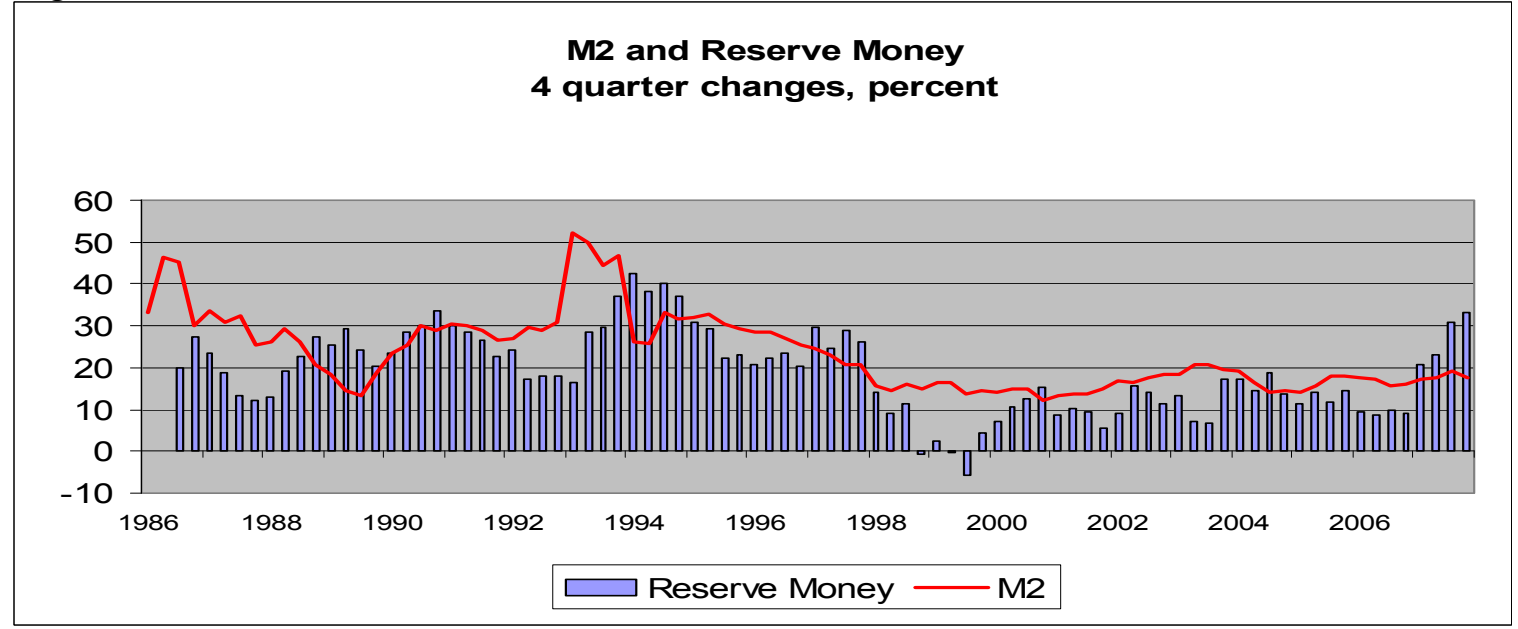

Figure 13.

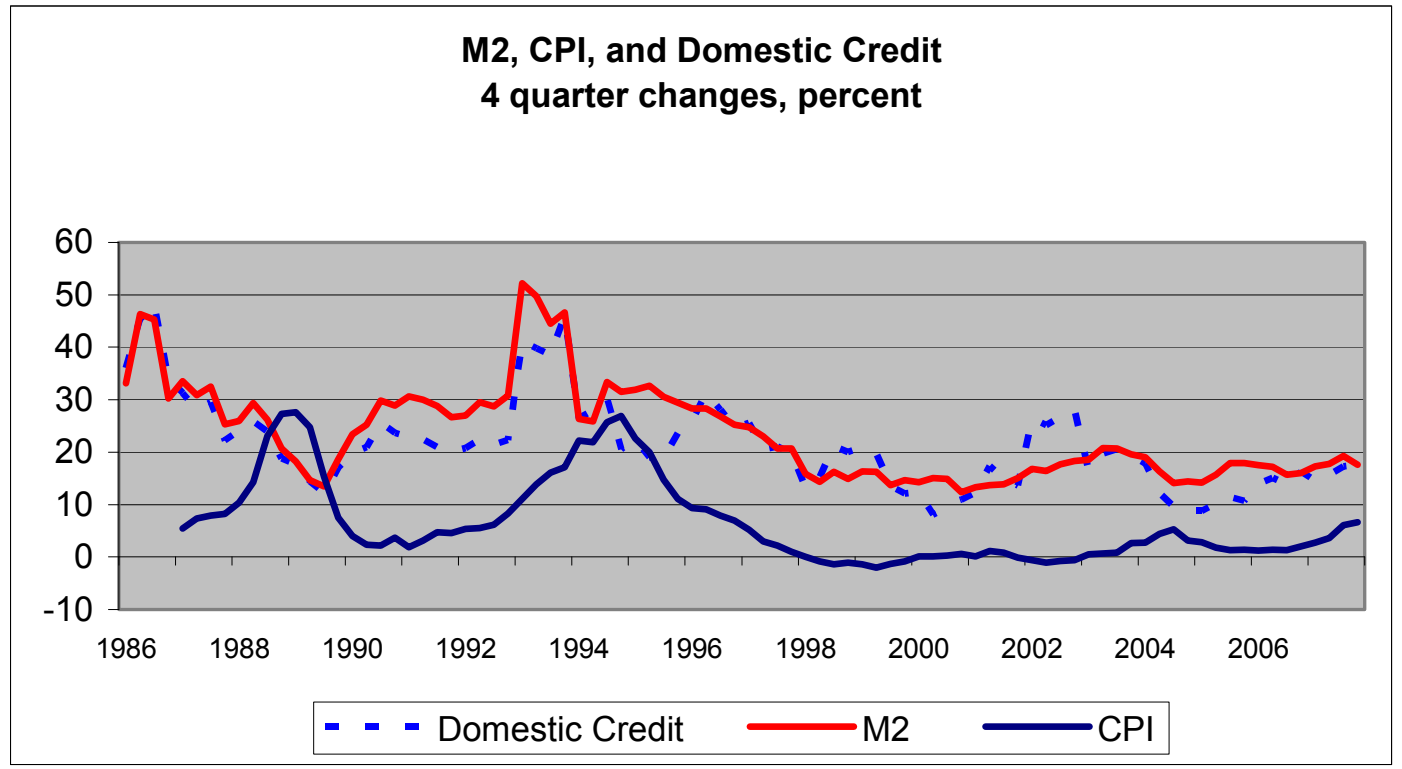


Figures 14. Sterilization Coefficients from 40-quarter rolling regressions

CHINA

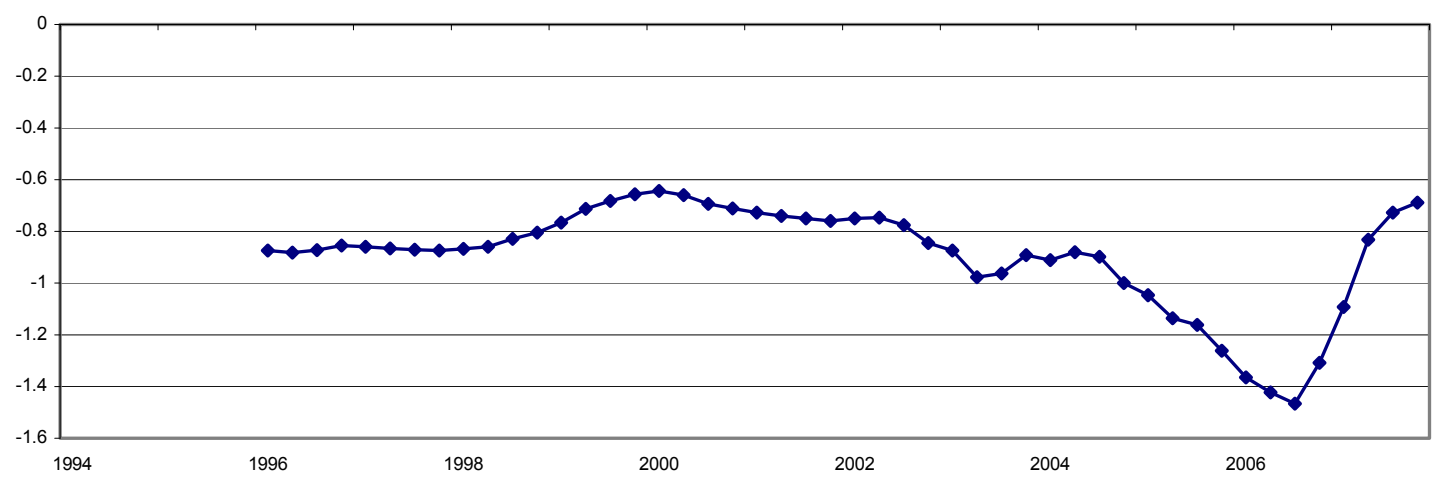

Note: Coefficient estimates from regression of net foreign asset change on net domestic asset change and nominal GDP growth. Coefficient observation correspond to calendar date of $40^{\text {th }}$ quarter of rolling sample period. 
Figure 15. Money Growth and Inflation Model, VECM Simulations

Scenario 1: Cortinusion of Forgin Reserve Buldep and High COP Crowh

CPI (vea $\$$ ch)

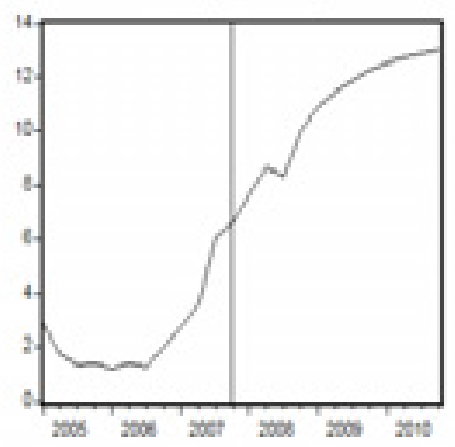

Real COP bear $\$ \mathrm{ch}$ )

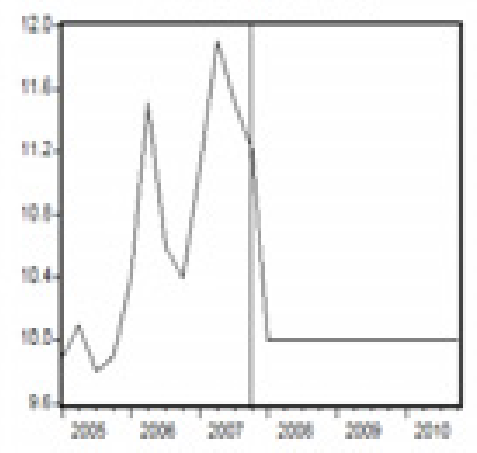

$\mathbb{M}$ (year $\$ \mathrm{sch}$ )

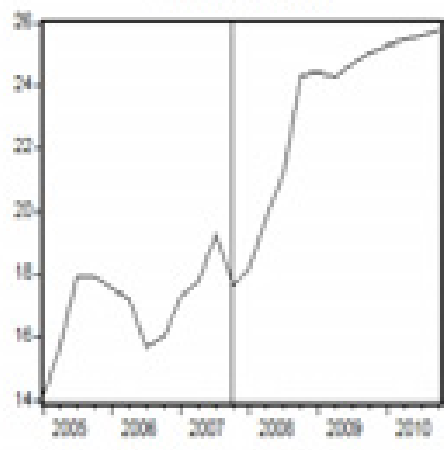

RM(vear \% ch)

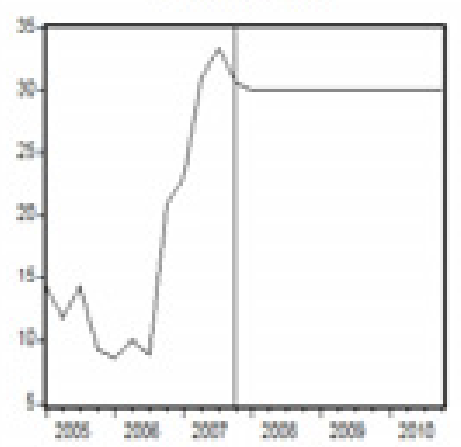

Scenario 2 Growh Slowdown and Fagid Reserve Growth CPI (year \% ch)

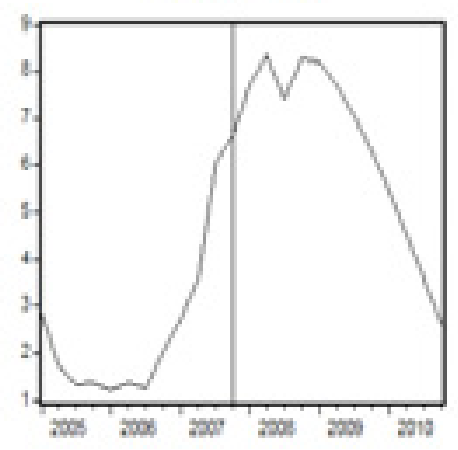

Real GOP (year $\$ \mathrm{ch}$ )

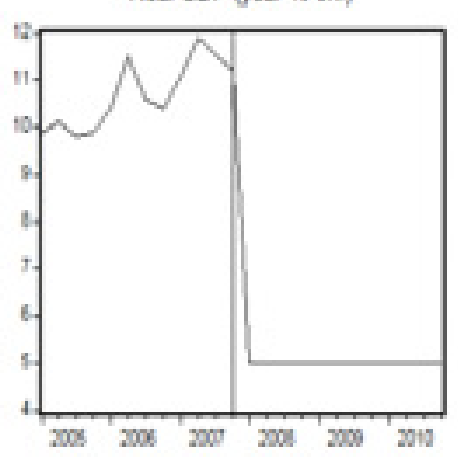

Me (year \$ ch)

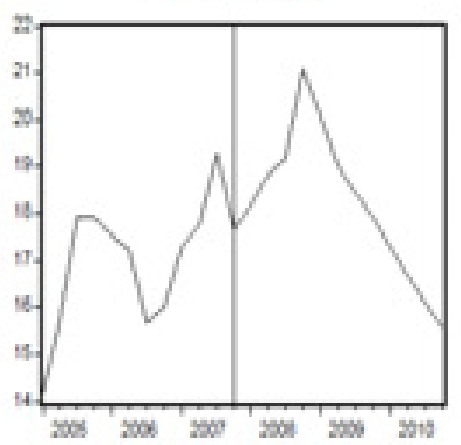

RM (yea $\$$ ch)

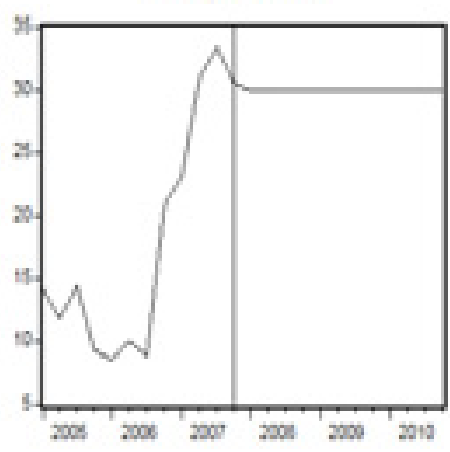


Table 1. China's Balance of Payments, 1985-2007 (billions of US\$)

\begin{tabular}{|c|c|c|c|c|c|c|c|c|c|c|c|c|c|c|c|}
\hline \multirow[b]{2}{*}{$\begin{array}{l}\text { Foreign reserve } \\
\text { accumulation }\end{array}$} & \\
\hline & 0.5 & 11.4 & 22.5 & 31.6 & 35.7 & 6.4 & 8.5 & 10.5 & 47.3 & 75.5 & 117.0 & 206.4 & 207.0 & 247.0 & 532.2 \\
\hline as \% of GDP & 0.1 & 2.4 & 3.1 & 3.7 & 3.8 & 0.6 & 0.8 & 0.9 & 3.6 & 5.2 & 7.1 & 10.7 & 9.3 & 9.3 & 16.2 \\
\hline Current account & -5.3 & 5.5 & 1.6 & 7.2 & 37.0 & 31.5 & 21.1 & 20.5 & 17.4 & 35.4 & 45.9 & 68.7 & 160.8 & 249.9 & 325.7 \\
\hline as \% of GDP & -1.6 & 1.4 & 0.2 & 0.8 & 3.9 & 3.1 & 1.9 & 1.7 & 1.3 & 2.4 & 2.8 & 3.6 & 7.2 & 9.4 & 9.9 \\
\hline Financial account & 6.4 & 13.4 & 38.7 & 40.0 & 21.0 & -6.3 & 5.2 & 2.0 & 34.8 & 32.3 & 52.8 & 110.7 & 58.9 & 6.0 & 177.4 \\
\hline as \% of GDP & & & 5.3 & 4.7 & 2.2 & -0.6 & 0.5 & 0.2 & 2.6 & 2.2 & 3.2 & 5.7 & 2.6 & 0.2 & 5.4 \\
\hline $\begin{array}{l}\text { Direct } \\
\text { investments, net }\end{array}$ & 1.8 & 13.6 & 33.8 & 38.1 & 41.7 & 41.1 & 37.0 & 37.5 & 37.4 & 46.8 & 47.2 & 53.1 & 67.8 & 60.3 & 101.8 \\
\hline $\begin{array}{l}\text { Securities } \\
\text { investment, net }\end{array}$ & na & 1.4 & 0.8 & 1.7 & 6.9 & -3.7 & -11.2 & -4.0 & -19.4 & -10.3 & 11.4 & 19.7 & -4.9 & -67.6 & -9.7 \\
\hline $\begin{array}{l}\text { Other } \\
\text { investments, net }\end{array}$ & na & -1.7 & 4.0 & 0.2 & -27.6 & -43.7 & -20.5 & -31.5 & 16.9 & -4.1 & -5.9 & 37.9 & -4.0 & 13.3 & 85.2 \\
\hline $\begin{array}{l}\text { Errors and } \\
\text { omissions }\end{array}$ & -0.6 & -7.5 & -17.8 & -15.6 & -22.3 & -18.7 & -17.8 & -11.9 & -4.9 & 7.8 & 18.4 & 27.0 & -16.8 & -12.9 & 26.2 \\
\hline $\begin{array}{l}\text { Memo: Non-FDI } \\
\text { financial account } \\
\text { (including errors } \\
\text { and omissions) }\end{array}$ & 3.9 & -7.7 & -13.0 & -13.7 & -42.9 & -66.1 & -49.6 & -47.4 & -7.4 & -6.7 & 24.0 & 84.6 & -25.7 & -67.1 & 101.7 \\
\hline as $\%$ of GDP & 1.2 & -1.5 & -1.8 & -1.6 & -4.5 & -6.5 & -4.6 & -4.0 & -0.6 & -0.5 & 1.5 & 4.4 & -1.2 & -2.5 & 3.1 \\
\hline $\begin{array}{l}\text { Memo: Stock of } \\
\text { Foreign Reserves }\end{array}$ & 3.3 & 25.0 & 73.6 & 105.0 & 139.9 & 145.0 & 154.7 & 165.6 & 212.2 & 286.4 & 403.3 & 609.9 & 818.9 & 1066.3 & 1528.2 \\
\hline as \% of GDP & 0.9 & 5.0 & 10.1 & 12.3 & 14.7 & 14.3 & 14.3 & 13.8 & 16.0 & 19.7 & 24.6 & 31.6 & 36.6 & 40.1 & 46.6 \\
\hline
\end{tabular}

Notes: Sum of current account, financial account, and errors and omissions differs (slightly) from reserve accumulation by omission of capital account. Change in stock of foreign reserves differs from reserve accumulation because of valuation and other effects to holdings. 
Table 2. China's Balance of Payments, 1998-2007 (billions of US\$)

\begin{tabular}{|c|c|c|c|c|c|c|c|}
\hline & $\begin{array}{l}\text { Avg. } \\
1998- \\
2000\end{array}$ & $\begin{array}{l}\text { Avg. } \\
2001- \\
2004\end{array}$ & $\begin{array}{l}\text { Avg. } \\
2005- \\
2006 \\
\end{array}$ & 2007 & $\begin{array}{c}\text { Change from } \\
1998-2000 \text { to } \\
2001-2004\end{array}$ & $\begin{array}{l}\text { Change from } \\
\text { L2001-2004 to } \\
2005-2006\end{array}$ & $\begin{array}{c}\text { Change from } \\
\text { 2005-2006 } \\
\text { to } 2007\end{array}$ \\
\hline $\begin{array}{l}\text { Foreign reserve } \\
\text { accumulation }\end{array}$ & 8.5 & 111.6 & 227.0 & 532.2 & 103.1 & 115.5 & 305.2 \\
\hline Current account & 24.4 & 41.8 & 205.3 & 325.7 & 17.5 & 163.5 & 120.4 \\
\hline Financial account & 0.3 & 57.7 & 32.4 & 177.4 & 57.4 & -25.2 & 145.0 \\
\hline $\begin{array}{l}\text { Direct } \\
\text { investments, net }\end{array}$ & 38.5 & 46.1 & 64.0 & 101.8 & 7.6 & 17.9 & 37.8 \\
\hline $\begin{array}{l}\text { Securities } \\
\text { investment, net }\end{array}$ & -6.3 & 0.3 & -36.2 & -9.7 & 6.7 & -36.6 & 26.6 \\
\hline $\begin{array}{l}\text { Other } \\
\text { investments, net }\end{array}$ & -31.9 & 11.2 & 4.6 & 85.2 & 43.1 & -6.6 & 80.6 \\
\hline $\begin{array}{l}\text { Errors and } \\
\text { omissions }\end{array}$ & -16.1 & 12.1 & -14.8 & 26.2 & 28.2 & -26.9 & 41.0 \\
\hline $\begin{array}{l}\text { Memo: Non-FDI } \\
\text { financial account } \\
\text { (including errors } \\
\text { and omissions) }\end{array}$ & -54.4 & 23.6 & -46.4 & 101.7 & 78.0 & -70.1 & 148.1 \\
\hline
\end{tabular}


Table 3. Money Growth and Inflation Model, Unit Root Tests

\begin{tabular}{l|ll} 
Variable & ADF & Prob.* $^{*}$ \\
\hline Log(RM) & -0.135943 & 0.9401 \\
Log(M2) & -1.668771 & 0.4416 \\
Log(CPI) & -1.805353 & 0.3756 \\
Log(RGDP) & 0.691381 & 0.991 \\
\hline
\end{tabular}

Notes:

Table reports augmented Dickey-Fuller test statistics (ADF) for null hypothesis of existence of unit root for prices (CPI), real GDP (RGDP), reserve money (RM), and M2.

Equations include constant and 4 lags.

*MacKinnon (1996) one-sided p-values.

Table 4. Money Growth and Inflation Model, Cointegration Tests

A. Unrestricted Cointegration Rank Test (Trace)

\begin{tabular}{|c|c|c|c|c|}
\hline Hypothesized No. of CE(s) & Eigenvalue & Trace Statistic & $\begin{array}{c}0.05 \\
\text { Critical Value } \\
\end{array}$ & Prob. $^{* *}$ \\
\hline None * & 0.575 & 87.982 & 47.856 & 0.000 \\
\hline At most $1^{*}$ & 0.366 & 35.752 & 29.797 & 0.009 \\
\hline At most 2 & 0.091 & 7.942 & 15.495 & 0.472 \\
\hline At most 3 & 0.034 & 2.091 & 3.841 & 0.148 \\
\hline \multicolumn{5}{|c|}{ B. Unrestricted Cointegration Rank Test (Maximum Eigenvalue) } \\
\hline Hypothesized No. of CE(s) & Eigenvalue & $\begin{array}{c}\text { Max-Eigenvalue } \\
\text { Statistic }\end{array}$ & $\begin{array}{c}0.05 \\
\text { Critical Value } \\
\end{array}$ & Prob.** \\
\hline None * & 0.575 & 52.230 & 27.584 & 0.000 \\
\hline At most 1 * & 0.366 & 27.810 & 21.132 & 0.005 \\
\hline At most 2 & 0.091 & 5.850 & 14.265 & 0.633 \\
\hline At most 3 & 0.034 & 2.091 & 3.841 & 0.148 \\
\hline
\end{tabular}

Notes:

Sample: 1992Q4-2007Q4, with 61 observations after adjustments.

System consists of prices (CPI), real GDP (RGDP), reserve money (RM), and M2, all in logs, with a linear deterministic trend and two lags of variables in first differences. A constant and 3 quarterly dummies not reported.

Trace test indicates 2 cointegrating eqn(s) at the 0.05 level.

Max-eigenvalue test indicates 2 cointegrating eqn(s) at the 0.05 level.

* denotes rejection of the hypothesis at the 0.05 level

${ }^{* *}$ MacKinnon-Haug-Michelis (1999) p-values 
Table 5. Money Growth and Inflation Model, VECM Estimates

A. Cointegrating Equations

\begin{tabular}{lrr} 
& CointEq1 & CointEq2 \\
\hline Log(M2_t-1) & 1.000 & 1.000 \\
Log(CPI_t-1) & -0.435 & 0.000 \\
& $(-4.091)$ & \\
Log(RM_t-1) & 0.000 & -1.166 \\
& & $(-14.550)$ \\
Log(RGDP_t-1) & -1.800 & 0.000 \\
\hline
\end{tabular}

B. Dynamics

\begin{tabular}{|c|c|c|c|c|}
\hline$\underline{\text { Variable }}$ & $\Delta(\log (M 2))$ & $\Delta(\log (\mathrm{CPI}))$ & $\Delta(\log (\mathbf{R M}))$ & $\Delta(\log ($ RGDP $))$ \\
\hline CointEq1 & $\begin{array}{r}-0.146 \\
(-4.042)\end{array}$ & $\begin{array}{r}-0.047 \\
(-3.517)\end{array}$ & $\begin{array}{r}-0.130 \\
(-2.323)\end{array}$ & $\begin{array}{r}0.290 \\
(3.483)\end{array}$ \\
\hline CointEq2 & $\begin{array}{r}-0.026 \\
(-1.015)\end{array}$ & $\begin{array}{r}0.015 \\
(1.572)\end{array}$ & $\begin{array}{r}0.085 \\
(2.110)\end{array}$ & $\begin{array}{r}0.099 \\
(1.656)\end{array}$ \\
\hline$\Delta\left(\log \left(\mathrm{M} 2 \_\mathrm{t}-1\right)\right.$ & $\begin{array}{r}0.093 \\
(0.694)\end{array}$ & $\begin{array}{r}0.173 \\
(3.518)\end{array}$ & $\begin{array}{r}-0.023 \\
(-0.110)\end{array}$ & $\begin{array}{r}-0.347 \\
(-1.130)\end{array}$ \\
\hline$\Delta\left(\log \left(\mathrm{M} 2 \_\mathrm{t}-1\right)\right)$ & $\begin{array}{r}-0.177 \\
(-1.296)\end{array}$ & $\begin{array}{r}-0.099 \\
(-1.965)\end{array}$ & $\begin{array}{r}0.300 \\
(1.419)\end{array}$ & $\begin{array}{r}1.478 \\
(4.695)\end{array}$ \\
\hline$\Delta(\log ($ CPI_t -1$))$ & $\begin{array}{r}0.007 \\
(0.019)\end{array}$ & $\begin{array}{r}0.366 \\
(2.779)\end{array}$ & $\begin{array}{r}-0.441 \\
(-0.795)\end{array}$ & $\begin{array}{r}-3.365 \\
(-4.078)\end{array}$ \\
\hline$\Delta(\log ($ CPI_t -2$))$ & $\begin{array}{r}0.205 \\
(0.752)\end{array}$ & $\begin{array}{r}0.290 \\
(2.892)\end{array}$ & $\begin{array}{r}0.755 \\
(1.791)\end{array}$ & $\begin{array}{r}3.267 \\
(5.208)\end{array}$ \\
\hline$\Delta(\log ($ RM_t -1$))$ & $\begin{array}{r}-0.044 \\
(-0.492)\end{array}$ & $\begin{array}{r}0.063 \\
(1.888)\end{array}$ & $\begin{array}{r}-0.069 \\
(-0.496)\end{array}$ & $\begin{array}{r}0.364 \\
(1.7522)\end{array}$ \\
\hline$\Delta(\log ($ RM_t -2$))$ & $\begin{array}{r}-0.089 \\
(-0.955)\end{array}$ & $\begin{array}{r}-0.001 \\
(-0.041)\end{array}$ & $\begin{array}{r}0.142 \\
(0.981)\end{array}$ & $\begin{array}{r}0.203 \\
(0.945)\end{array}$ \\
\hline$\Delta(\log ($ RGDP_t-1) $)$ & $\begin{array}{r}-0.085 \\
(-1.159)\end{array}$ & $\begin{array}{r}-0.028 \\
(-1.030)\end{array}$ & $\begin{array}{r}-0.108 \\
(-0.948)\end{array}$ & $\begin{array}{r}-0.180 \\
(-1.069)\end{array}$ \\
\hline$\Delta(\log ($ RGDP_t -2$))$ & $\begin{array}{r}-0.056 \\
(-1.055)\end{array}$ & $\begin{array}{r}-0.018 \\
(-0.930)\end{array}$ & $\begin{array}{r}-0.037 \\
(-0.450)\end{array}$ & $\begin{array}{r}0.263 \\
(2.159)\end{array}$ \\
\hline R-squared & 0.564 & 0.933 & 0.802 & 0.692 \\
\hline Adj. R-squared & 0.443 & 0.915 & 0.747 & 0.607 \\
\hline Sum sq. resids & 0.019 & 0.003 & 0.045 & 0.099 \\
\hline S.E. equation & 0.020 & 0.007 & 0.031 & 0.046 \\
\hline F-statistic & 4.676 & 50.532 & 14.606 & 8.114 \\
\hline Log likelihood & 160.096 & 221.095 & 133.435 & 109.218 \\
\hline Akaike AIC & -4.790 & -6.790 & -3.916 & -3.122 \\
\hline Schwarz SC & -4.306 & -6.306 & -3.431 & -2.637 \\
\hline Mean dependent & 0.047 & 0.012 & 0.042 & 0.020 \\
\hline S.D. dependent & 0.027 & 0.025 & 0.061 & 0.073 \\
\hline \multirow{3}{*}{\multicolumn{2}{|c|}{$\begin{array}{l}\text { Resid. Cov.: Log likelihood } \\
\text { Resid. Cov.: Akaike inform.criterion } \\
\text { Resid. Cov.: Schwarz criterion }\end{array}$}} & 630.029 & & \\
\hline & & -18.558 & & \\
\hline & & -16.344 & & \\
\hline
\end{tabular}

Notes:

Sample: 1992Q4-2007Q4, with 61 observations after adjustments. t-statistics in ( ). 
Appendix Figure 1. Unadjusted and adjusted reserve money growth (12 month growth rates, in percent)

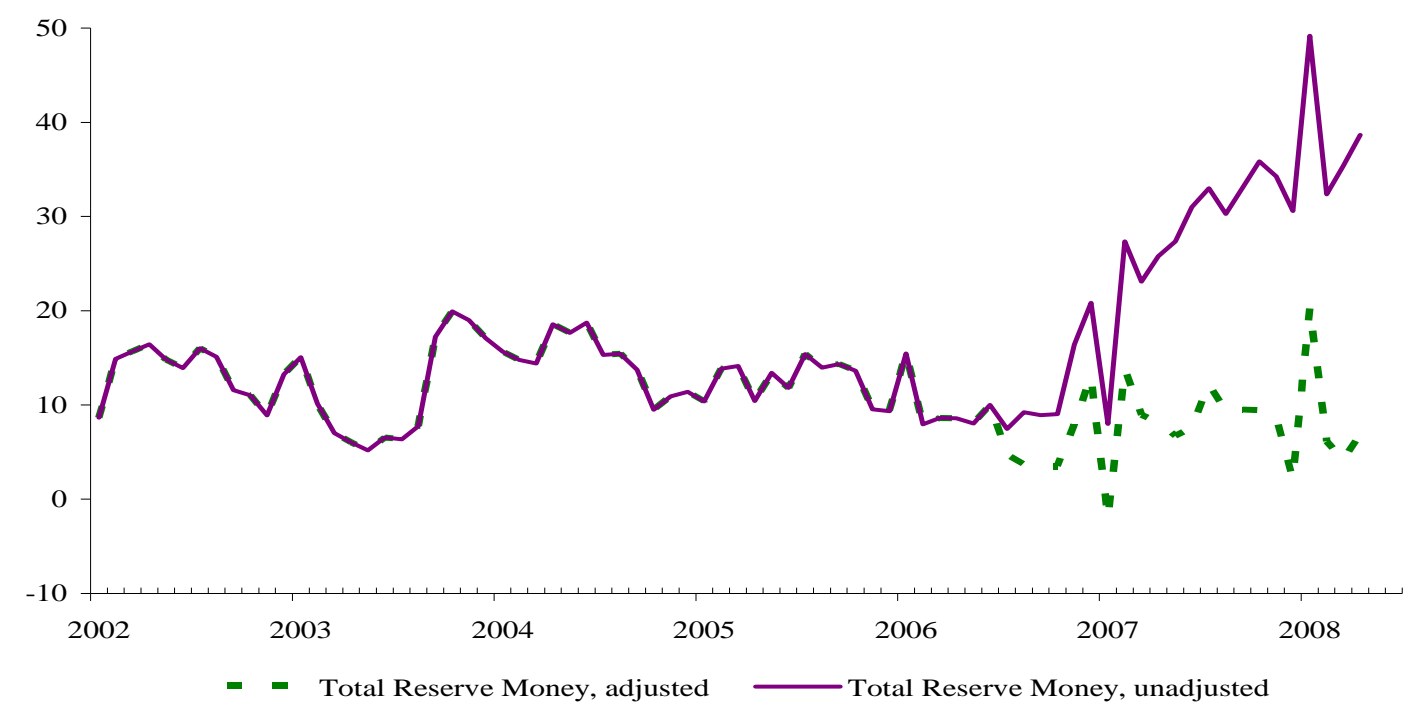


Appendix Figure 2. Money Growth and Inflation Model, VECM Simulations

Scenario 1A Rapid GDP Growth and Moderate Reserve Money (Adjusted) Growth

CPI (year \% ch.)

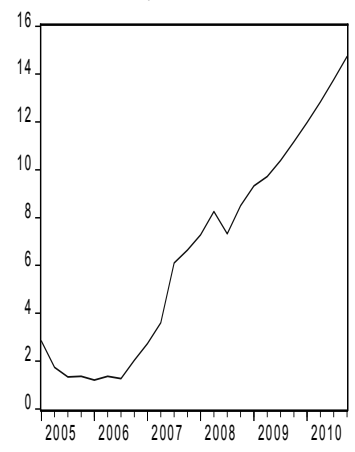

Real GDP (year \% ch.)

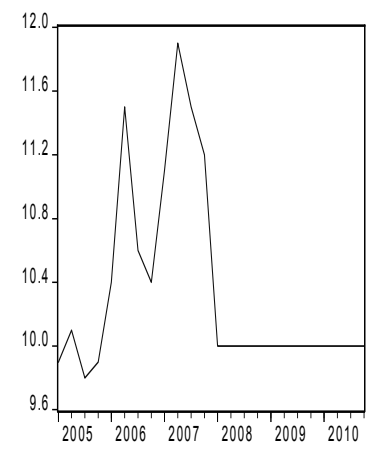

M2 (year \% ch.)

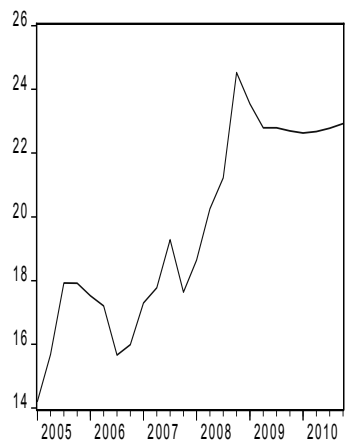

Adjusted Reserve Money (year \% ch.)

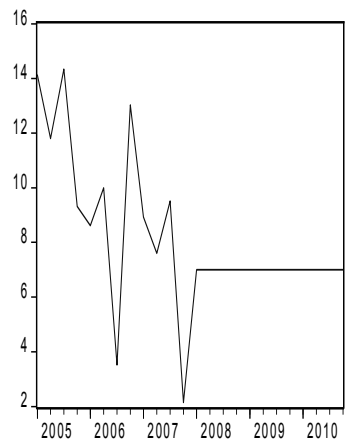

Scenario 2A Growth Slowdown and Moderate Reserve (Adjusted) Growth CPI (year \% ch.)
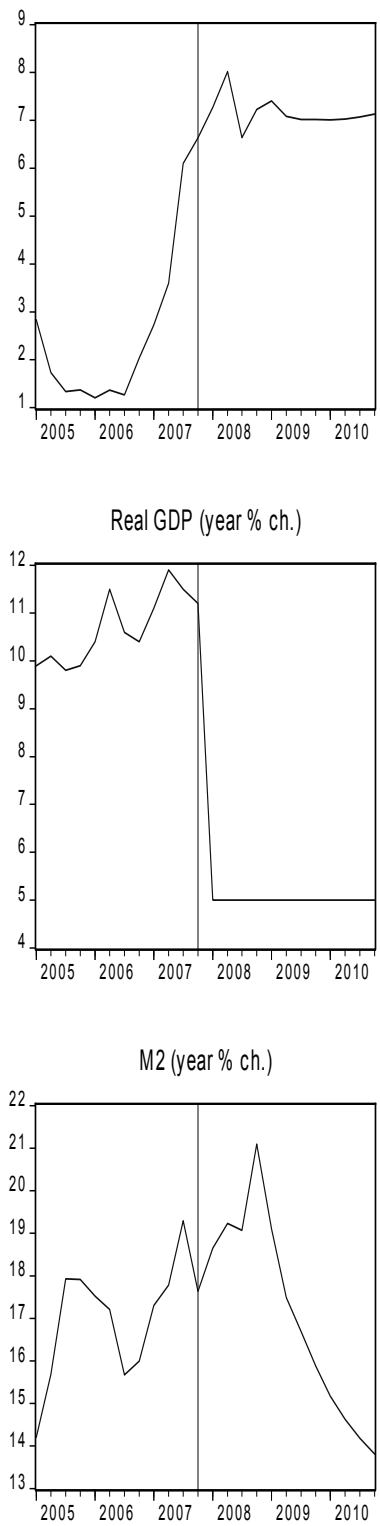

Adjusted Reserve Money Growth (year \% ch.)

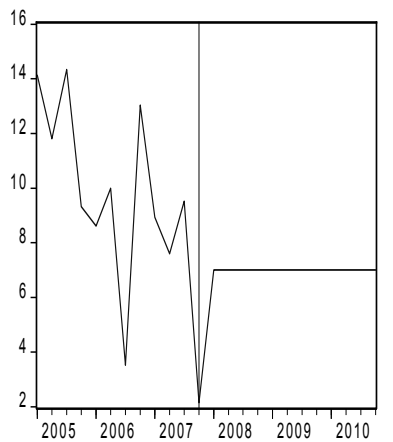


Appendix Table 1. Money Growth and Inflation Model, Cointegration Tests

A. Unrestricted Cointegration Rank Test (Trace)

\begin{tabular}{|c|c|c|c|c|}
\hline Hypothesized No. of CE(s) & Eigenvalue & Trace Statistic & $\begin{array}{c}0.05 \\
\text { Critical Value } \\
\end{array}$ & Prob.** \\
\hline None * & 0.535 & 77.684 & 47.856 & 0.000 \\
\hline At most 1 * & 0.287 & 31.011 & 29.797 & 0.036 \\
\hline At most 2 & 0.152 & 10.382 & 15.495 & 0.253 \\
\hline At most 3 & 0.006 & 0.346 & 3.841 & 0.556 \\
\hline
\end{tabular}

B. Unrestricted Cointegration Rank Test (Maximum Eigenvalue)

\begin{tabular}{lrrrr}
\hline & \multicolumn{4}{c}{ Max-Eigenvalue } \\
Hypothesized No. of CE(s) & \multicolumn{1}{c}{$\begin{array}{c}0.05 \\
\text { Critical Value }\end{array}$} & Prob. ** $^{*}$ \\
\hline None * & 0.535 & 46.674 & 27.584 & 0.000 \\
At most 1 * & 0.287 & 20.629 & 21.132 & 0.059 \\
At most 2 & 0.152 & 10.035 & 14.265 & 0.210 \\
At most 3 & 0.006 & 0.346 & 3.841 & 0.556 \\
\hline
\end{tabular}

Notes:

Sample: 1992Q4-2007Q4, with 61 observations after adjustments.

System consists of prices (CPI), real GDP (RGDP), reserve money (RM), and M2, all in logs, with a linear deterministic trend and two lags of variables in first differences. A constant and 3 quarterly dummies not reported.

Trace test indicates 2 cointegrating eqn(s) at the 0.05 level.

Max-eigenvalue test indicates 2 cointegrating eqn(s) at the 0.05 level.

${ }^{*}$ denotes rejection of the hypothesis at the 0.05 level

${ }^{* *}$ MacKinnon-Haug-Michelis (1999) p-values

Appendix 2. Money Growth and Inflation Model, VECM Estimates

\section{A. Cointegrating Equations}

\begin{tabular}{lrr} 
& CointEq1 & CointEq2 \\
\hline Log(M2_t-1) & 1.000 & 1.000 \\
Log(CPI_t-1) & -0.410 & 0.000 \\
& $(-3.983)$ & \\
Log(RM_t-1) & 0.000 & -1.418 \\
& & {$[-33.398]$} \\
Log(RGDP_t-1) & -1.800 & 0.000 \\
\hline
\end{tabular}

Note: Dynamic equation estimates are available upon request. 